Girgin, D. ve Şahin, Ç. (2020). Sınıf öğretmeni adaylarının üstbilişsel okuma stratejilerini kullandırma düzeyleri: Bir karma yöntem çalışması. Ana Dili Eğitimi Dergisi, 8(4), 1149-1173.

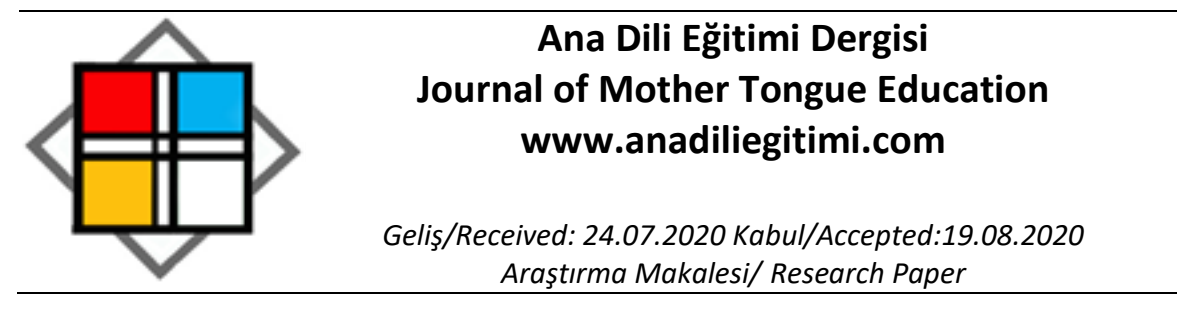

\title{
Sınıf Öğretmeni Adaylarının Üstbilişsel Okuma Stratejilerini Kullandırma Düzeyleri: Bir Karma Yöntem Çalışması*
}

\author{
Derya GIRGIN** \\ Çavuş ŞAHIN ${ }^{* * *}$
}

\begin{abstract}
Öz
$\mathrm{Bu}$ araştırmanın amacı sınıf öğretmeni adaylarının üstbilişsel okuma stratejilerini kullandırma düzeylerini belirlemektir. Bu amaç doğrultusunda araştırmada nitel ve nicel bulguların yorumlama aşamasında birleştirildiği karma yöntem deseni olarak yakınsayan desen kullanılmıştır. Nicel veriler Özen ve Durkan (2016) tarafından geliştirilen Üstbilişsel Okuma Stratejileri Kullandırma (ÜBOSK) ölçeğinden, nitel veriler ise sınıf öğretmeni adaylarının öğretmenlik uygulaması I kapsamında Türkçe derslerinde gözlemlenmesiyle elde edilmiştir. Nicel verilerinin çözümlenmesinde parametrik olan alt boyutlar için $t$ testi ve tek yönlü varyans analizi testi; parametrik olmayan alt boyutlar için ise Mann Whitney U Testi ve Kruskal Wallis H Testi SPPS paket programı kullanılarak yapılmıştır. Gözlem formu aracılığıyla elde edilen nitel verilerde betimsel analiz kullanılmıştır. Araştırmada öğretmen adaylarının not ortalaması ve cinsiyet gibi bireysel özelliklerinin ÜBOSK üzerinde fark yarattığı; öğretmen adaylarının Türkçe dersinde gözlem yapmalarının bu stratejileri kullandırmada etkili olduğu ama Türkçe dersinde uygulama yapmanın bu stratejileri etkin kılmada fark yaratmadığı sonucuna ulaşılmıştır. Öğretmen adaylarının sınıf içinde ÜBSOK da özellikle okuma esnası ve okumayı değerlendirme kısımlarında yeterli davranış sergileyemedikleri gözlemlenmiştir. Araştırma sonuçları ışığında bu stratejilere yönelik öğretmen yetiştirme programlarında meslek bilgisi dersleri kapsamında uygulamalar içeren eğitimlerin verilmesi ve çeşitli teknikler ile öğretim tasarımları geliştirilmesi önerilmektedir.
\end{abstract}

Anahtar Kelimeler: Üst biliş, okuma stratejileri, üstbilişsel okuma stratejileri, sınıf öğretmeni adayı, öğretmen eğitimi, karma yöntem

\section{Levels of Primary School Teacher Candidates' Getting the Students to Use Metacognitive Reading Strategies: A Mixed Method Research}

\begin{abstract}
The objective of this study is to determine the levels of primary school teacher candidates' getting the students to use metacognitive reading strategies. For this purpose, the convergent pattern was used as a mixed methods pattern in which the qualitative and quantitative findings were combined in the interpretation phase. The quantitative data were obtained using the Metacognitive Reading Strategies Utility Scale developed by Özen and Durkan (2016), whereas the qualitative data were obtained by observing the primary school teacher candidates in Turkish lessons within the scope of Teaching Practice I. In the analysis of the quantitative data, t-test and one-way analysis of variance test were used for parametric sub-dimensions, whereas Mann Whitney U Test and Kruskal Wallis H Test SPPS package program were used for non-parametric sub-dimensions. Descriptive
\end{abstract}

\footnotetext{
* Araştırmanın etik kurulu izni: Çanakkale Onsekiz Mart Üniversitesi Sosyal Bilimler ve Eğitim Bilimleri Etik Kurulu 15/06/2020 karar tarihli 2020/80 belge sayı numaralı izin ile çalışma gerçekleştirilmiştir.

** Dr. Öğr. Üyesi Derya GiRGiN, Çanakkale Onsekiz Mart Üniversitesi, Eğitim Fakültesi, Özel Eğitim Bölümü, Çanakkale, deryagirgin@comu.edu.tr, ORCID: 0000-0002-6114-7925

*** Prof. Dr. Çavuş ŞAHIN, Çanakkale Onsekiz Mart Üniversitesi, Eğitim Fakültesi, Temel Eğitim Bölümü, Çanakkale, csahin25240@yahoo.com, ORCID: 0000-0002-4250-9898
} 
analysis was used in the qualitative data obtained through the observation form. In the research, it was found out that the individual characteristics of the primary school teacher candidates, such as grade point average and gender, made a difference on the Metacognitive Reading Strategies Utility Scale and that the primary school teacher candidates' observations in Turkish lessons were effective in getting the students to use these strategies although practicing in Turkish lessons did not make a difference in terms of making these strategies effective. It was observed that the primary school teacher candidates were not able to display adequate behavior in the classroom, especially in the during reading and reading evaluation sub-dimensions. In the light of the results of the research, it is recommended to provide trainings with applications within the scope of vocational knowledge courses in teacher education programs for these strategies, and to develop instructional designs by developing various techniques.

Keywords: Metacognitive, reading strategies, metacognitive reading strategies, primary school student teacher, teacher education, mixed method research

\section{Giriş}

Günümüz eğitim sisteminde öğrenci merkezli anlayış ile öğrencilerin kendi zihinsel potansiyellerini geliştirmelerine, yeni bilgileri daha önceden öğrenmiş oldukları bilgilerle yapılandırmalarına imkân veren bir anlayış söz konusudur. Bu bağlamda öğrencilerin öğrenme sürecine aktif katılım gösterdikleri, bilgiyi kendi öğrenme çerçevelerinde yapılandırdıkları ve yeniden düzenledikleri bir öğrenme yapısı karşımıza çıkmaktadır (Baker, Dreher ve Guthrie 2000). Öğrencilerin kendi öğrenmelerinin farkına varması, meta bilişselliği yani düşünme sürecinde beyinin işleyiş sürecinin önemini karşımıza çıkarmaktadır (Papleontiou-Louca, 2003). Meta bilişsellik; üst biliş, yürütücü biliş ya da biliş ötesi gibi farklı adlandırmalarla bireylerin sahip olduğu bilgi ve inançlar ile ne yapabileceğinin farkında olmasına işaret etmektedir. Bu bağlamda öğrencilerin nasıl öğrenebileceğini fark etmesi ve bilmesi üst biliş kavramı ile açıklanmaktadır. Alan yazın irdelendiğinde üst biliş kavramına ait birçok tanıma rastlanmaktadır (Hartman, 2001; Mokhtari ve Reichard, 2002). Üst biliş, kişinin kendi bilişsel süreçleri ve ürünleri ya da onlarla ilgili her şey hakkındaki bilgisi olarak tanımlanmaktadır (Pressley, 2002). Schraw (2001) meta-bilişsel düşünmenin kişinin düşünce farkındalığına hitap ettiğini ve farklı öğrenme durumlarında kullanılan süreçlerle ilgili olduğunu vurgulamaktadır. Edwards, Weinstein, Goetz ve Alexander (2014) meta bilişsel bilginin kişinin düşünme süreçlerinin bilinci olduğunu ifade etmektedir. Vagle (2009) ise meta bilişsel düşünceyi zihinsel aktivitenin en üst seviyesine koymaktadır, çünkü meta bilişsel düşünme süreci bireylerin kendilerinin ve başkalarının farkında olmalarını sağlamaktadır. Stewart ve Landine (1995) göre üst biliş kavramı; bireylerin düşünme sürecine duyarlı katılımını temel alan, öğrencilerin öğrenmesinde önemli rol üstlenen bir kavramdır. Bu bağlamda üst biliş, insanların kendi bilgi işleme becerileri, bilişsel görevlerin doğası ve çeşitli görevlerle başa çıkma stratejileri hakkındaki bilgilerini ifade etmektedir (Flavell,1979). Ayrıca üst biliş birlikte kişinin kendi bilişsel faaliyetlerinin izlenmesi ve kendi kendini düzenlemesiyle ilgili yönetici becerileri de içermektedir (Artelt ve Schneider 2015). Özetle üst biliş; bireylerin düşünmesini analiz edip kontrol etmeyi sağlayan, bilgi üretimini aktif ve kolay hale getiren; bilişsel davranışları, yetenekleri planlayıp, organize edip, değişime imkân sağlayan bir kavramdır (Noushad, 2008; Sutiyatno ve Sukarno,2019; Wilson, 2001). Eğitim bağlamında üst biliş, öğrencilerin okul başarısını etkileyen temel bir özellik olarak ifade edilmiştir (Wang, 1990). Graham (2003), öğrencilerin öğrenmelerini planlayabilmelerini, kontrol edebilmelerini ve incelemelerini sağlayan üstbilişsel stratejilerin önemli olduğunu açıklamaktadır. Üstbilişsel stratejiler, seçme ve değerlendirme becerilerinden başka özsaygı, kendine güven, değer ve çalışmadaki bağımsızıı̆ı da kazandırmada da oldukça önemlidir (Boghian, 2016; Dinner, 2009; Li, 2008; Schneider, 2010). Üst biliş, çalışma alanındaki öğrenme deneyimlerini geliştirerek, öğrencilerin üstbilişsel stratejiler odağında öğrenme gelişimlerini analiz etmelerinde de önemli bir rol üstlenmektedir (Mokhtari ve Reichard, 2002). Böylelikle üstbilişsel stratejiler öğrencilerin düşüncelerini derin bir öğrenme ve gelişmiş performansa dönüştürebilmektedir. Üstbilişsel stratejiler öğrencilerin ne yapacaklarını tasarlayarak yeni öğrenmeler için gelişim göstermelerindeki bilinçli olarak kullanılan süreç olarak eğitimde önemli bir yere sahiptir.

Bilişsel bir süreç olarak, okuma sürecinde meta bilişselliğin öne çıkartılması okuduğunu anlamada oldukça önemlidir. Iwai (2011) göre üst biliş; dilbilimsel, bilişsel ve sosyal becerilerin gelişimi 
ile ilgili olduğu için okuduğunu anlamada önemli bir rol oynamaktadır, çünkü okuyucuların okuma performansları üzerinde eleştirel bir şekilde düşünmelerine imkân tanımaktadır. Okuduğunu anlama sırasındaki süreci üst biliş; sistematik, amaçlı, planlı, temel ve kolaylaştırıcı gibi özelliklere sahip stratejilerle açıklanmaktadır (Alexander ve Jetton, 2000). Üstbilişsel stratejilere sahip okuyucular, metinleri etkili bir şekilde analiz etmek ve bu konudaki yeteneklerini geliştirmek için bir veya daha fazla üstbilişsel strateji kullanmaktadır (Pressley ve Afflerbach, 1995). Steinbach (2010) üst biliş stratejileri becerilerinin planlama, problem çözme, etkinliği izleme, öz değerlendirme, öz düzeltme ve öz değerlendirme durumlarına katkısını önemle vurgulamaktadır. Ulusal Okuma Paneli (NPR) (2000) üstbilişsel stratejilerin okuduğunu anlamada olumlu katkıda bulunduğunu teyit etmiştir. Bu noktada üst biliş üç faktörle ilişkilidir: (a) devam eden okuma sürecine yansıma, (b) bu yansıma tarafından harekete geçirilen stratejik faaliyetler ve (c) üstbilişsel bilgi tabanı ile ortaya konan faaliyetler (Artelt ve Schneider, 2015). Üstbilişsel stratejiler aracılı̆ıyla öğrenciler okuma sürecini kontrol etme, izleme ve değerlendirme konusunda yetkin olurlar (Pressley, 2000; Pressley ve McCormick,1995). Bu çerçevede bilişsel süreçleri anlamak ve yönetmek, öğretmenlerin öğrencilerinin başarılarını artırmak için yürütebileceği en önemli becerilerden biri olabilmektedir. Alan yazında birçok çalışma, öğrencilerin okuma stratejileri konusundaki üstbilişsel bilgilerinin, okuduğunu anlama becerileri ile olumlu ilişkili olduğunu göstermektedir (Artelt, Schiefele ve Schneider, 2001; Artelt ve Schneider, 2015; KolićVehovec, Rončević Zubković ve Pahljina-Reinić, 2014; Roeschl-Heils, Scheider ve Krayenood,2003; Van Gelderen, Schoonen, Stoel, De Glopper ve Hulstijn, 2007). Bununla birlikte birçok çalışmada okuduğunu anlama çeşitli disiplinlerde akademik başarı için bir önkoşul niteliğindedir. Çünkü okuduğunu anlama, metin bilgilerinin zihinsel bir temsilinin oluşturulması için çok yönlü bir süreçtir (Cano, García, Justicia ve García-Berbén, 2014; O’Reilly ve McNamara 2007; Vista 2013). Okuma stratejileri; bireylerin bilgi edinmek, organize etmek, detaylandırmak ve kendi metin anlamalarını yansıtmak, yönlendirmek için seçilen zihinsel faaliyetler olarak okumada önemli bir rol oynamaktadır (Andreassen ve Bråten 2011). Artelt ve Schneider (2015), okuma stratejilerinin üstbilişsel bilgisi ile okuduğunu anlama arasındaki ilişkinin doğada karşılıklı olduğunu, üstbilişsel bilginin okuduğunu anlama üzerindeki etkisine ek olarak ayrıca anlamsal gelişime katkıda bulunduğunu belirtilmektedir.

Üstbilişsel okuma stratejileri, üst bilişin-bilişsel kaynakları ile görev talepleri arasındaki ilişkinin okuma sürecine uygulanması, farkındalığı ve izlenmesi olarak ifade edilmektedir. Bu nedenle üstbilişsel okuma stratejileri, okuma sürecini kontrol etmek, izlemek ve değerlendirmek için tasarlanmış faaliyetleri içermektedir (Pressley, Brown, El-Dinary, Allferbach,1995; Pressley, 2000). Yeni bilgileri öğrenilmiş bilgilerle bütünleştirme olarak okumayı planlamayı olukça önemlidir (Wade, Trathen ve Schraw, 1990). Bireylerin okuduğunu anlaması da kelime bilgisi yetenekleri ve konunun ön bilgisi ile bağlantılıdır (Cromley ve Azevedo, 2007; Cromley, Snyder-Hogan ve Luciw-Dubas, 2010).

Bilgiyi özetleme, kendi kendine sorgulama ve önceki öğrenmeler ile yeniyi bağlama, metinden çıkarımı teşvik eden unsurların da okuduğunu anlama üzerinde doğrudan önemli bir etkisi olduğu bulunmuştur (Cromley ve Azevedo, 2007; Cromley ve ark., 2010). Papleontiou -Louca (2003) metabilişselliği biliş hakkındaki bilgi olarak tanımlamaktadır, metabiliş çünkü okuma / düşünme sürecinde beynin işleyişini odağına alır. Bilişsel bir süreç olarak okumak, okuma sürecinde metabilişin, farkındalığın düzenlenmesinin daha iyi anlaşılmasına yol açabileceğini ima eder. Iwai'ye (2011) göre, üstbiliş, bazı dilbilimsel, bilişsel ve sosyal becerilerin geliştirilmesinde gerekli olduğu için okuduğunu anlamada anahtardır. Okuma alanında üstbilişsel stratejiler, öğrencileri okuma görevleri yaparken düşüncelerinden haberdar eden faaliyetlerdir. Khezrlou (2012) bir metni analiz etmek için okurken, öğrencilerin çeşitli stratejiler kullandıklarını açıklamıştır: (1) bilişsel: tahmin etme, çeviri, özetleme, daha önceki bilgi veya deneyim ile bağlantı kurma, dilbilgisi kuralları kullanma, metinden anlamı tahmin etme, (2) üstbilişsel: öz değerlendirme, planlama, kişinin öğrenme sürecini izleme gibi.

Okuduğunu anlama genellikle kelimelerin okunması, kelimelerin bilgisi, metin organizasyonu, stratejiler gibi bir dizi karmaşık süreci koordine ederek anlamın kurulduğu bir süreç olarak tanımlanır (Cain, Oakhill ve Bryant, 2004; Fuchs, Fuchs, Hosp ve Jenkins, 2001; Paris, Carpenter, Paris ve Hamilton, 2005; Sheorey ve Mokhtari,2001). Anastasiou ve Griva (2009) okuma stratejilerini okuyucunun bir metni deşifre etme, kelimeleri anlama ve bir metnin anlamını oluşturma çabalarını kontrol eden ve değiştiren spesifik, kasıtlı, hedefe yönelik zihinsel süreçler veya davranışlar olarak tanımlamaktadır. 
Üstbilişsel okuma stratejileri bireylerin bilişsel bir görevi yerine getirirken devam eden performanslarını izlemelerini ve değerlendirmelerini sağlayan rutin prosedürlerdir (Dole, Nokes ve Drits, 2009). Araştırmalar, okuyucuların amaçlarına ulaşmak için uygun üstbilişsel okuma stratejilerini seçme ve etkili bir şekilde kullanma becerisi olduğunu göstermiştir (Klingner, Urbach, Golos, Brownell ve Menon, 2010; Pressley ve Harris, 2009). Okuma süreci üst biliş ile bütünleştirildiğinde üç temel strateji ortaya çıkar. Bunlar; planlama (okuma öncesi), izleme (okuma sırası) ve değerlendirme (okuma sonrası) stratejileridir. Bunlar üstbilişsel okuma stratejilerinde üç tür sınıflandırma ile örtüşmektedir: planlama, izleme ve değerlendirme (Anderson, 2012). Okumadan önce planlama için üstbilişsel okuma stratejilerinin örnekleri, ön bilgileri etkinleştirmek, bir başlığı, resimleri, çizimleri, başlıkları veya alt başlıkları incelemek ve metin yapısının uzunluğunu ön izlemektir (Almasi, 2003). Okuma sırasında izleme, kendi kendine sorgulamayı, anlayışı kontrol etmeyi, hangi parçalara odaklanacağını belirlemeyi, önemli bilgileri aramayı ve okuma hızını okuma amacına göre ayarlamayı; okuduktan sonra stratejileri değerlendirmeyi, okuyucuların okuduklarını ve özetlediklerini yansıtmayı içerir (Israel, 2007; Pressley, 2002).

Eğitim alanında öğretmenler öğrencilerinin duygu ve eylemleri için yeteneklerini ortaya koymada, öğretme öğrenme sürecini daha rahat ve başarılı hale getirmede, öğrencilerinin bilişsel süreçlerini yönlendirmede önemli bir rol üstlenmektedir (Azevado ve ALeven, 2013). Öğretmenler öğrencilerin farklı metinler üzerinde deneyim elde etmelerini sağlamalı; öğrencilerin okuma öncesinde, okuma esnasında ve okuma sonrasında metin ile ilgili görüşlerini almalı; öğrencilerin okuma amacını oluşturmasına yardımcı olmalı, çıkarımlarda bulunmaları için cesaretlendirmeli ve öğrencilerin yeni öğrendikleri bilgileri önceden öğrendikleriyle bütünleştirmelerine yardımcı olmalıdır (Block ve Pressley, 2007).

Öğretmenlerin eğitimde üstbilişsel yaklaşımları kullanmasının en önemli nedeni öğrenciler üzerindeki etkisiyle ilişkili olmasıdır. Üstbilişsel farkındalık, öğrencileri öğrenmenin zor unsurlarıyla başa çıkma yollarında, problemlerin üstesinden gelmek için kısa yollarını geliştirmede önemlidir (Mclnerney, 2013). Houtveen ve Van de Grift (2007), okuma stratejisi öğretiminin öğrencilerin üstbilişsel bilgisi üzerinde olumlu bir etkisi olduğunu bulmuştur. Alan yazında okuma stratejisi öğretiminin öğrencilerin okuma stratejisi kullanımı ile pozitif ilişkileri olduğu (Andreassen ve Bråten, 2011; Cantrell, Almasi, Carter, Rintamaa ve Madden, 2010) okuduğunu anlama başarısı sağladığı ve okuma eğitiminin öğretmenin okuma ile ilgili üstbilişsel bilgisinden önemli ölçüde etkilendiği (Andreassen ve Bråten 2011; Houtveen ve Van de Grift, 2007) tespit edilmiştir.

Öğrencilerin üstbilişsel okuma stratejilerini geliştirmek için öğretmenlerin çok çeşitli stratejiler hakkında profesyonel bilgiye sahip olmaları ve öğrencilere bu stratejiler hakkında açık yönergeler vermeleri gerekmektedir (Curwen, Miller, White-Smith ve Calfee, 2010). Araştırmalar öğretmenlerin stratejileri açıkça öğrettiklerinde öğrencilerin üstbilişsel okuma stratejilerini öğrenebileceklerini ve anlamalarını geliştirebileceklerini göstermiştir (Block ve Israel, 2005; Edmonds, Vaughn, Wexler, Reutebuch, Cable, Tackett ve Schnakenberg, 2009).

Sınıf içerisinde okuduğunu anlamada üstbilişsel becerilerin yapılandırılması ile okunan metinlerin değerlendirilmesi öğrencinin birçok becerisini geliştirir (Block ve Israel, 2005; Duffy, 2005). Öğrencilerin okuduğunu anlama becerilerinin geliştirilmesi için öğretmenlerin nitelikli bir eğitim süreci planlamaları gerekmektedir. Öğrencilerin üstbilişsel okuma stratejilerini kullanmalarında özellikle sınıf öğretmenlerinin önemli bir rolü vardır. Çünkü sınıf öğretmenleri okuma ve anlama çalışmalarının hayat boyu temelini oluşturmaktadır. Sınıf öğretmenleri öğrencilerine okuma ve okuduğunu anlama eğitimi konusunda üstbilişsel stratejileri kullanacak şekilde derslerini yapılandırmalıdır. Bu bağlamda sınıf öğretmenleri derslerinde üstbilişsel okuma stratejilerini geliştiren uygulamalar yaparak, üstbilişsel stratejilerin kullanımını öğrencilerine kazandırabilir. Çünkü sınıf öğretmeni bu stratejilerin kullanımının sağlanmasında model olabilir. Alan yazında öğretmenlerin okuma öğretimi ile ilgili çeşitli uygulamalarını inceleyen bazı çalışmalara rastlanılmaktadır (Miller, 2006; Ness, 2006). Ülkemizde ise farklı branşlarda öğretmenlerin ya öğretmen adaylarının üstbilişsel okuma stratejilerine ne ölçüde sahip olduklarını ortaya koyan çalışmalar vardır (Ataalkın, 2012; Başaran, 2013; Çeçen ve Alver, 2011; Dilci ve Kaya, 2012; Karakelle ve Saraç, 2010). Alan yazında yapılan çalışmalar irdelendiğinde hizmet öncesinde özellikle okuma çalışmalarının temelini atan sınıf öğretmeni adaylarının üstbilişsel okuma 
stratejilerini kullandırmaya yönelik nitel ve nicel verilerin birleşiminden oluşan karma model yaklaşımında bir araştırmaya rastlanılmamıştır. Araştırma bu yönüyle alan yazına katkı sağlayarak, temel dil becerisi olan okuma alanına ilişkin hizmet öncesi eğitimde öğretmen adaylarının bu stratejiler hakkındaki niteliği ve etkililiği hakkında bilgi verici olacaktır.

Araştırmanın amacı; sınıf öğretmeni adaylarının üstbilişsel okuma stratejilerini kullandırma düzeylerini belirlemektir. Araştırmada sınıf öğretmeni adaylarının öğretmenlik uygulaması kapsamında üstbilişsel okuma stratejilerini kullandırma düzeylerinin tespit edilmesi, hizmet öncesi dönemde adayların bu stratejilerin kullandırılmasında ne kadar etkin olduğunun ortaya konması açısından önemli olduğu düşünülmektedir. Bu amaç doğrultusunda şu sorulara cevap aranmıştır:

1.Sınıf öğretmeni adaylarının, öğrencilerine üstbilişsel okuma stratejilerini kullandırmaları ne düzeydedir?

2.Sınıf öğretmeni adaylarının öğretmenlik uygulamasında öğrencilerine üstbilişsel okuma stratejilerini kullandırma düzeyleri,

a. Cinsiyetlerine,

b. Genel not ortalamalarına,

c. Öğretmenlik uygulaması kapsamında Türkçe dersinde uygulama yapma durumlarına,

d. Okul deneyimi kapsamında Türkçe dersinde gözlem yapma durumlarına göre farklııı göstermekte midir?

3.Sınıf öğretmeni adaylarının öğretmenlik uygulamasında öğrencilerine üstbilişsel okuma stratejilerini kullandırma durumlarına yönelik ders içerisinde gözlenen davranışları nelerdir?

\section{Araştırmanın Modeli}

\section{Yöntem}

Bu araştırma karma yöntem deseni olarak yapılandırılmıştır. Araştırma süreci işlenirken nitel ve nicel yaklaşımların bir arada kullanıldığı karma araştırma; bir yöntemin zayıf yönlerinin diğerinin güçlü yönleriyle tamamlanması esasına dayalı bir desendir (Creswell, 2009; Creswell ve Plano Clark, 2011; Morse ve Niehous, 2009). Karma yöntem desenlerindeki dinamik yaklaşımlar araştırma deseninin bileşenleri arasındaki bağıntı sürecine odaklanmaktadır (Maxwell ve Loomiss, 2003). Bu araştırmada karma yöntem olarak nitel ve nicel bulguların karşılıklı olarak doğrulanması için çeşitlendirmenin gerçekleştirildiği yakınsayan desen kullanılmıştır (Leech ve Onwuegbuzie, 2007). Yakınsayan desende araştırmanın nicel ve nitel aşamaları eş zamanlı olarak uygulamaya konulur, nicel ve nitel yöntemin her ikisinin de eşit önceliğe sahip olduğu bu desende ayrı veri çözümleme sürecinden sonra yorumlama yapılırken birleştirme yapılır (Creswell ve Plano Clark,2011; Johnson ve Christensen, 2019; Morse ve Niehaus, 2009). Bu bağlamda karma yakınsayan desende yapılandırılan bu çalışmanın verileri arasında yorumlama aşamasında birleştirme yapılmıştır. Araştırma deseninin modeli Şekil 1' de verilmiştir.

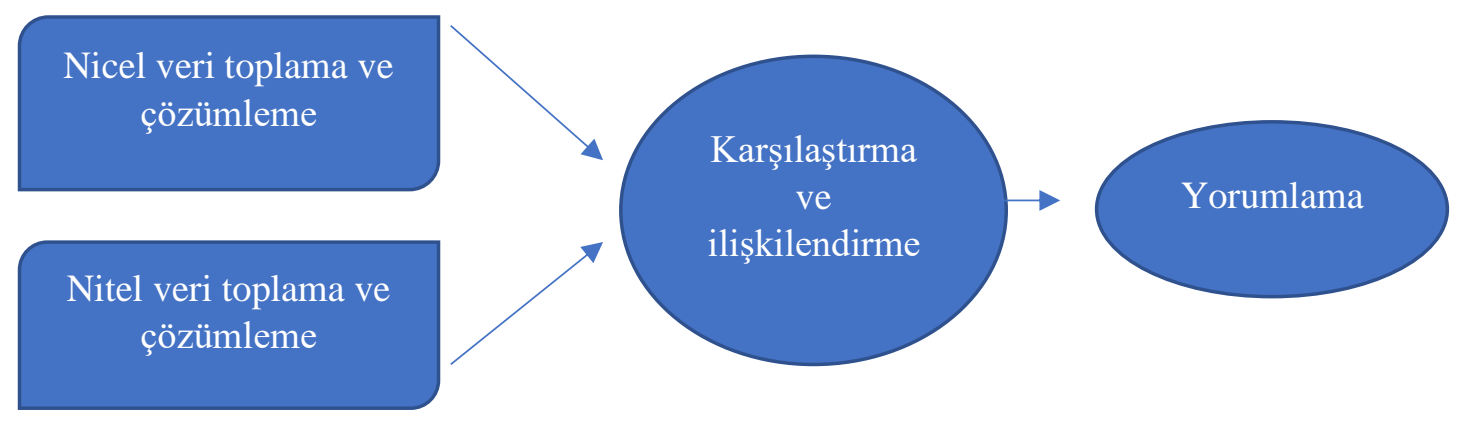

Şekil 1.Araştırmanın Deseninin Şematik Gösterimi (Yakınsayan Desen)

Şekil 1'de görüldüğg̈ü üzere araştırmada eş zamanlı olarak nicel ve nitel verilerin toplandığı, ayrı nitel ve nicel verilerin analizlerinin yapılıp iki veri grubunun karşılaştırılarak, ilişkilendirilerek yorumlandığı yakınsayan desen kullanılmıştır. Araştırmada konunun eksiksiz anlaşılmasının sağlanması, nicel bağlamdaki sonuçların doğrulanmasının sağlanması ve felsefi anlamda şemsiye paradigması ile 
pragmatizm varsayımlarından yola çıkarak araştırma probleminin tek ve geniş çerçeveden anlaşılmasının sağlanması için birleştirme yapılarak yorumlanması için yakınsayan desen kullanılmıştır. Bu desen bir problem durumunun hem nicel hem de nitel olarak verileri toplamada ve analiz etmede eşit değere sahip olduğunda, kısıtlı zaman dilimi söz konusu olduğunda kullanılmaktadır (Creswell, 2017; Ivankova ve Kawamura, 2010; Silverman, 2013). Araştırmada sınıf öğretmeni adaylarının üstbilişsel okuma stratejilerini kullandırma düzeylerinin belirlenmesi noktasında nicel verilerin ve nitel verilerin sadece öğretmenlik uygulaması I dersi kapsamında toplanması söz konusu olduğundan araştırmada bu desen seçilmiştir.

Nicel Bölüm: Araştırmanın nicel bölümü, var olan durumu olduğu şekliyle betimlemeyi hedefleyen tarama modeli olarak yürütülmüştür (Büyüköztürk, Kılıç-Çakmak, Akgün, Karadeniz ve Demirel, 2011; Karasar, 2014). Bu kapsamda sınıf öğretmeni adaylarının üstbilişsel okuma stratejilerini kullandırma durumları ve bu durumların farklı değişkenine göre incelenmesi gerçekleştirilmiştir.

Nitel Bölüm: Araştırmanın nitel bölümünde durum çalışması gerçekleştirilmiştir. Durum çalışmalarında bütüncül bir sistem içerisinde bir ya da birden çok olay, ortam, programın derinlemesine analizi söz konusudur (Best ve Kahn, 2017; Cohen, Manion ve Morrison, 2005; Merriam, 2002; Yıldırım ve Şimşek, 2013; Yin, 2003). Durum çalışması yaklaşımı kapsamında, üstbilişsel okuma stratejilerini kullandırma içeriğine uygun olarak araştırmacılar tarafından hazırlanan gözlem formu aracılığıyla öğretmenlik uygulamasında Türkçe derslerinde gözlem yapılmıştır.

Bu çalışmanın sınıf öğretmeni adaylarının Öğretmenlik Uygulaması I dersi kapsamında gerçekleştirilmesi; nitel veri toplama aracı olan gözlemin sadece Türkçe derslerinde yapılması, üç farklı okul, altı farklı sınıfta dört hafta yürütülmesi araştırmanın sınırıııkları içerisinde yer almaktadır. Bununla birlikte araştırmanın nicel bölümünde sınıf öğretmeni adaylarının ölçme aracında yer alan maddelere içten, samimi ve dürüst cevaplar verdikleri varsayılmaktadır.

\section{Örneklem / Araştırma grubu}

Nicel Çalışma Grubu: Araştırmanın çalışma grubunu, 2019-2020 öğretim yılı Çanakkale Onsekiz Mart Üniversitesi Eğitim Fakültesi Temel Eğitim Bölümü Sını Öğretmenliği Anabilim Dalında öğrenim gören toplam 114 öğretmen adayı oluşturmaktadır. Öğretmen adaylarının seçiminde amaçlı örnekleme yaklaşımlarından ölçüt örnekleme çeşidi kullanılmıştır. Amaçlı örnekleme bazı analiz birimleri ya da durumlarının seçkisiz olarak değil, belli bir amaç doğrultusunda seçilmesi işlemidir (Büyüköztürk, Çakmak, Akgün, Karadeniz ve Demirel, 2014; Tashakkori ve Teddlie, 2003). Bu araştırmada lisans eğitiminde öğretim derslerini almış olmak, lisans son sınıf öğrencisi olmak ölçütleri bağlamında sınıf öğretmeni adaylarından nicel çalışma grubu belirlenmiştir.

Nitel Çalışma Grubu: Araştırmanın amacı kapsamında gerçekleşen gözlem için amaçı örnekleme yöntemlerinden ölçüt örnekleme yöntemiyle belirlenen sınıf öğretmeni adayları nitel çalışma grubunu oluşturmaktadır (Teddlie ve Yu,2007). Araştırmanın nitel çalışma grubuna ölçüt örnekleme yöntemiyle sınıf öğretmeni adayları belirlenirken farklı sınıf düzeylerinde, Türkçe derslerinde öğretmenlik uygulaması I temel ölçütler olarak belirlenmiştir. Ölçüt örnekleme yaklaşımı ile daha önceden belirlenen ölçütlere uygun olan öğretmen adaylarının çalışmaya katılması amaçlanmıştır (Yıldırım ve Şimşek, 2013). Ayrıca sınıf öğretmen adayları için Öğretmenlik Uygulaması dersi kapsamında uygulama okullarının farklı sosyo ekonomik düzeyde olması ve uygulama sınıflarının farklı öğretim kademelerinde olması da ölçüt olarak belirlenmiştir. Araştırma sürecinde 12 sınıf öğretmeni adayı üstbilişsel okuma stratejilerini kullandırma odağında gözlemlenmiştir. Nitel çalışmaların örneklem büyüklüğüne karar verilmesinde temel esas doygunluk noktasına ulaşılması ile ilgilidir. Durum çalışması için kişilerle yapılan çalışmaların 6 ile 24 kişi arasında olması alan yazında belirtilmektedir (Mertens,2005; Miles ve Huberman,2015). Araştırmada gözlem yapılan sınıf öğretmeni adaylarının özellikleri Tablo 1'de verilmiştir.

Tablo 1.

Gözlem Yapılan Öğretmen Adaylarının Özellikleri

\begin{tabular}{llll}
\hline $\begin{array}{l}\text { Öğretmen } \\
\text { Adayları }\end{array}$ & Cinsiyet & $\begin{array}{l}\text { Öğretmen } \\
\text { Adayları }\end{array}$ & Cinsiyet \\
\hline
\end{tabular}


Sınıf Öğretmeni Adaylarının Üstbilişsel Okuma Stratejilerini Kullandırma Düzeyleri: Bir Karma Yöntem Çalışması

\begin{tabular}{llll}
\hline SÖA1 & $K$ & SÖA7 & $E$ \\
\hline SÖA2 & $K$ & SÖA8 & $K$ \\
\hline SÖA3 & $E$ & SÖA9 & $K$ \\
\hline SÖA4 & $K$ & SÖA10 & $K$ \\
\hline SÖA5 & $E$ & SÖA11 & $E$ \\
\hline SÖA6 & $K$ & SÖA12 & $E$ \\
\hline
\end{tabular}

SÖA: Sınıf Öğretmeni Adayı

Tablo 1'de görüldüğg̈ü üzere öğretmenlik uygulaması kapsamında Türkçe dersinde öğrencilere üstbilişsel okuma stratejilerini kullandırma bağlamında gözlemlenen sınıf öğretmeni adayları 12 (5 erkek, 7 kadın) olduğu görülmektedir.

\section{Veri Toplama Araçları}

Araştırmada nicel veriler Özen ve Durkan (2016) tarafından geliştirilen Üstbilişsel Okuma Stratejileri Kullandırma (ÜOSK) ölçeğinden yararlanılarak elde edilmiştir. Nitel verilerin toplanmasında sınıf öğretmeni adaylarının üstbilişsel okuma stratejilerini kullandırmada sergilemiş oldukları davranışların tespiti için ise sınıf içi gözlemlerden yararlanılmıştır. Bu veri toplama araçlarına ait detaylı bilgiler nitel ve nicel veri toplama araçları olmak üzere alt başlıklarda sunulmuştur.

Nicel Veri Toplama Araçları: ÜOSK ölçeği dört alt faktörden oluşmaktadır. Bu faktörler; okumaya hazırlık (5 madde), okuma esnası (5 madde), okuma sonrası (7 madde) ve okuduğunu değerlendirme (8 madde) olarak adlandırılmıştır. Ölçek iki bölümden oluşmaktadır. Illk bölümde sınıf öğretmeni adaylarının kişisel bilgilerinin yer aldığı kısım, ikinci bölüm ise 25 maddeden ve dört faktörden oluşan öğretmen adaylarının üstbilişsel okuma stratejilerini kullandırmaya yönelik görüşlerinin yer aldığı kısımdır. Ölçeğin tümüne ilişkin güvenirlik katsayısı .90 olarak bulunurken; okumaya hazırlık faktörü için .70, okuma esnası faktörü için .79, okuma sonrası faktörü için .79 ve okuduğunu değerlendirme faktörü için .82 olarak bulunmuştur. Ölçeğin tümü ve alt boyutlar için elde edilen Cronbach Alpa değerleri .70 ile .90 arasında değişmektedir. Ölçeğin ve alt boyutlarının yüksek düzeyde güvenirliğe sahip olduğu görülmüştür. Araştırmada likert tipi ölçek için sınıf öğretmeni adaylarının görüşleri derecelendirme ölçeğine uygun olarak 4.20 - 5.00= Her Zaman Uygulanabilir, 3.40 - 4.19= Çoğunlukla Uygulanabilir, 2.60 - 3.39= Orta Düzeyde Uygulanabilir, 1.80 - 2.59= Nadiren Uygulanabilir, $1.00-1.79=$ Hiç Uygulanamaz, 0.00 - 0.99= Fikrim Yok seçenek sınırları içinde değerler kullanılarak düzeyleri belirlenmiştir.

Nitel Veri Toplama Araçları: Nitel araştırmalarda gözlem, araştırmacının araştırmaya konu olan olay, olgu ve duruma ilişkin derinlemesine ve ayrıntılı açıklamalar yapmasına olanak sağlamaktadır (Yıldırım ve Şimşek, 2013). Katılımcıların kendi doğal ortamlarında olmaları, gözlenecek davranışların yansız olarak ortaya çıkarılmasında ve konuşulmayanların davranışlar yoluyla fark edilmesi noktasında oldukça etkili olduğu düşünülmektedir (Karasar, 2014; Patton, 2014). Bu araştırmada sınıf öğretmeni adaylarının ÜOSK Ölçeği'nin alt boyutlarını nasıl ve ne kadar uyguladığı ortaya koymak amacıyla yarı yapılandırılmış gözlem formu oluşturulmuştur. Gözlem formu üç bölümden oluşmaktadır. İlk bölüm gözlem yapılan okul, sınıf düzeyi, öğrenci sayısı, gözlem tarihi ve saati gibi bilgileri içeren kısım, ikinci bölüm sınıf öğretmeni adaylarının üstbilişsel okuma stratejileriyle ilgili maddeleri, üçüncü bölüm gözlenen davranışların nasıl yapıldığıyla ilgili detaylı betimlemeler yapılacak "açıklama bölümü" şekilde tasarlanmıştır. Gözlem formunda davranışlar "Gözlendi" ve "Gözlenmedi" olmak üzere ikili derecelendirme şeklinde yapılandırılmıştır. Gözlemler öğretmenlik uygulaması I kapsamında 4 hafta boyunca Türkçe derslerinde gerçekleştirilmiştir. Gözlem formu kullanılarak araştırmanın amaçları çerçevesinde veri oluşturacak notlar alınmıştır. Gözlemler sınıf dinamiğini bozmayacak şekilde en arka sıraya tüm sınıf içi etkileşimlerin gözlemlenebileceği yere oturularak gerçekleştirilmiştir.

Gözlem yapılan sınıfların fiziksel özellikleri incelendiğinde, sınıflarda geleneksel sınıf düzeninin olduğu, öğrencilerin sıralarda ikişerli oturduğu, sınıf mevcutlarının 25-35 öğrenci arasında değişim gösterdiği, sınıf içinde teknolojik araç-gereçlerin bulunduğu (bilgisayar, yazıcı, akıllı tahta, hoparlör, projeksiyon) olduğu görülmüştür. 


\section{İşlem / Verilerin Toplanması}

Araştırmadan elde edilen tüm veriler 2019-2020 öğretim yılı içerisinde toplanmıştır.

Nicel Verilerin Toplanması: Araştırma amacı kapsamında toplanan nicel veriler 10-15 dakikalık bir uygulama sürecinde toplanmıştır. Nicel bölümünde sınıf öğretmeni adaylarının sürece katılımda gönüllü olmaları esas alınarak, ölçme aracında yer alan maddelere içten, samimi ve dürüst cevaplar verdikleri varsayılmaktadır.

Nitel Verilerin Toplanması: Araştırmadaki gözlem süreci, öğretmenlik uygulaması I dersi kapsamında dört haftalık bir süre içerisinde, toplamda üç farklı okul, altı farklı sınıfta yürütülmüştür. Sınıf öğretmen adayının gözlendiği günler ve dersler okul müdürleri ile sınıf öğretmenleriyle yapılan iş birliği ile belirlenmiştir. Gözlemler, eğitim alanında uzman iki araştırmacı tarafından katılımsız gözlem şeklinde, eş zamanlı ve birbirinden bağımsız bir biçimde gerçekleştirilmiştir. Katıımcı olmayan gözlem, içerisinde araştırmacının herhangi bir katılım göstermeyip sadece gözlemci olduğu, kimliğinin, araştırmanın ve süresinin açıkça belli olduğu gözlem türüdür (Ekiz, 2003). Araştırmada iletişimsel dil öğretim ilkeleri açısından sistemli bir yaklaşım benimsenmek istendiğinden yarı yapılandırılmış gözlem formuyla ortaya konmuştur. Yarı yapılandııılmış gözlemler gözlenecek şeyle ilgili daha iyi bir yapılanma ve sistematik yaklaşım sunmaktadır (Büyüköztürk, Çakmak, Akgün, Karadeniz ve Demirel, 2014). Nitel bölümde sınıf öğretmeni adaylarının gözlemlenmesi için kendilerinden onay alınmıştır.

\section{Verilerin Analizi}

Nicel Veri Analizi: Araştırmada ÜOSK ölçeğinden toplanan nicel verilerin analizi SPPS paket programı kullanılarak yapılmıştır. Adayların nicel verilerinin çözümlenmesinde aritmetik ortalama, standart sapma, frekans, yüzde, verilerde normallik (Bu bağlamda ölçekteki verilerin basıklık ve çarpıklık ölçüleri, Kolmogorov-Simirnov testlerine bakılmıştır. Parametik olan alt boyutlar için t testi ve tek yönlü varyans analizi ANOVA testi; parametrik olmayan alt boyutlar için ise Mann Whitney U Testi ve Kruskal Wallis H Testi kullanılmıştır. Gruplar arası karşılaştırmada anlamlılık ( $p$ değeri) 0,05 düzeyinde değerlendirilmiştir. Araştırmada toplanan verilerin normal dağılım gösterip göstermediğinin belirlenmesi amacıyla Kolmogorov-Smirnov normallik testi uygulanmıştır. Tablo 2'de araştırmaya katılan sınıf öğretmeni adaylarının üstbilişsel okuma stratejilerini kullandırma ölçeğinin boyutlarına ilişkin Kolmogorov-Smirnov testi sonuçları verilmiştir.

Tablo 2.

Sınıf Öğretmeni Adaylarının Üstbilişsel Okuma Stratejilerini Kullandırma Ölçeğinin Boyutlarına ilişkin Kolmogorov-Smirnov Normallik Testi

\begin{tabular}{llll}
\hline & \multicolumn{3}{c}{ Kolmogorov-Smirnov } \\
\cline { 2 - 4 } & Statistic & $\mathrm{df}$ & $\mathrm{p}$ \\
\hline Okumaya hazırlık &, 122 & 114 &, 000 \\
\hline Okuma esnası &, 081 & 114 &, 065 \\
\hline Okuma sonrası &, 151 & 114 &, 000 \\
\hline Okuduğunu değerlendirme &, 094 & 114 &, 014 \\
\hline ÜOSKÖ Toplam &, 125 & 114 &, 000 \\
\hline
\end{tabular}

Tablo 2'de görüldüğü üzere okumaya hazırlık, okuma sonrası ve ölçeğin tamamında okuduğunu değerlendirme Kolmogorov-Smirnov testi sonuçlarına göre $p$ değerleri $p<0,05^{\prime}$ den küçük olduğu için normal dağıım göstermezken, okuma esnasında boyutunun ise $p>0,05^{\prime}$ den $(p=, 065)$ büyük olduğu için normal dağılım gösterdiği tespit edilmiştir.

Nitel Veri Analizi: Gözlem formu aracılığıyla elde edilen veriler ve araştırmacının gözlem sırasında tuttuğu notların analiz sonuçları da betimsel şekilde ifade edilmiştir. Sınıf öğretmeni adaylarının üstbilişsel okuma stratejilerini kullandırmalarına ilişkin gözlemlerden elde edilen analiz sonuçları tablolar ile sunulmuştur. 
Araştırma Uygulama Akış Şeması: Araştırmada eş zamanlı olarak nicel ve nitel araştırmaya eşit ağılık verilerek süreç yapılandırılmıştır. Yakınsayan karma desen yaklaşımında gerçekleştirilen araştırmanın akış şeması şu şekildedir:

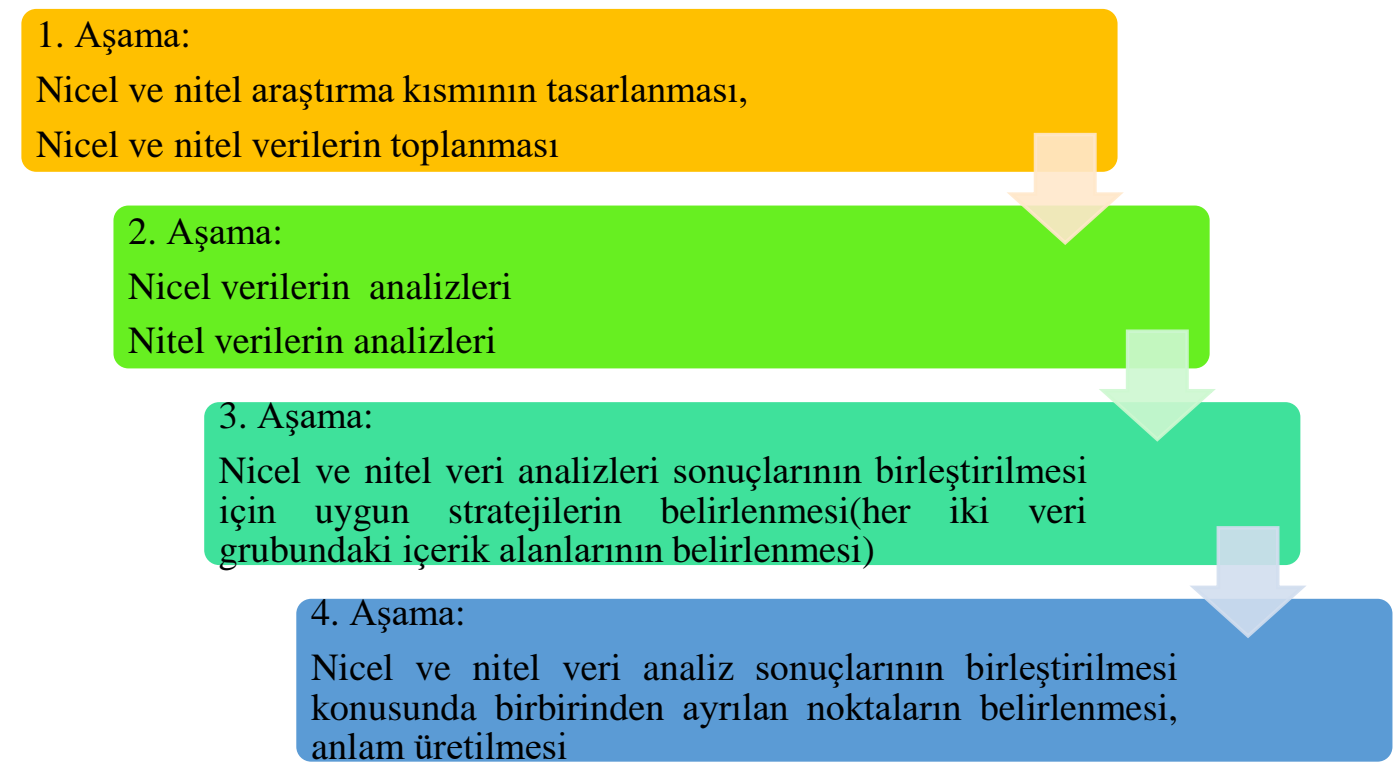

Şekil 2. Yakınsayan Desen Uygulama Aşaması (Creswell ve Plano Clark ,2011)

Yakınsayan karma desen yaklaşımına ilişkin dört adımda gerçekleştirilen araştırmada ilk aşamada nicel ve nitel veriler toplanmıştır. Bu noktada veri toplamanın bu iki türünde eş zamanlı gerçekleşmesi yani bir veri grubunun sonuçları diğer veri grubunun sonuçlarına dayanmamaktadır. Böylece araştırmada çalışma sonuçların ulaşmak için eşit bir önemin olduğunun da kanıtıdır. İkinci aşamada araştırma verileri birbirinden ayrı ve bağımsız olarak analiz edilmiştir. Üçüncü aşamada ise verilerin içerik alanları ölçeğin alt boyutları çerçevesinde belirlenerek sentezlenme stratejisi belirlenmiştir. Son aşamada iki veri kümesinin ilişkilendirilmesi sonuçların dönüştürülmesi yorumlamanın yapılması söz konusudur.

\section{Geçerlik ve Güvenirlik}

Araştırmanın nitel kısmı için geçerlik ve güvenirlik çalışmaları için öncelikle gözlem formu için veri toplama aracı hakkında uzman görüşü alınması, verilerin kaynağının kontrol ettirilmesi ve öğretmen adaylarının sürece etkin olarak katılım göstermeleri iç geçerliliğin sağlanmasında önemlidir (Merriam, 2013). Araştırmada dış geçerliliğin sağlanma durumuna ilişkin olarak ayrıntılı bir tanımlama yapılmıştır. Araştırmanın nitel kısmı için belirli ölçütlerin (inandırıcılık, onaylanabilirlik, güvenebilirlik) sağlanması önemlidir (Araştaman, Öztürk Fidan ve Fidan, 2018; Shenton, 2004). Araştırmaya katılan sınıf öğretmeni adayları SÖA1, SÖA2, ..., SÖA12 şeklinde kodlanmıştır.

\section{Etik Kurulu İzni}

Veri toplama araçları Çanakkale Onsekiz Mart Üniversitesi Sosyal Bilimler ve Eğitim Bilimleri Etik Kurula sunulmuş; aşağıda bilgileri sunulan karar ile çalışmanın araştırma ve yayın etiğine uygun olduğu belirtilmiştir:

Kurul adı =Çanakkale Onsekiz Mart Üniversitesi Sosyal Bilimler ve Eğitim Bilimleri Etik Kurulu Karar tarihi $=15 / 06 / 2020$

Belge sayı numarası $=2020 / 80$

Araştırmada nicel ve nitel verilerin toplanılmasında öğretmen adayları bilgilendirilmiş, gönüllü olur/onam formları da imzalatılarak araştırma süreci yapılandırımıştır. Ayrıca araştırmada kullanılan Özen ve Durkan (2016) tarafından geliştirilen Üstbilişsel Okuma Stratejileri Kullandırma (ÜOSK) ölçeği kullanımı için ölçek geliştiricilerden e-posta ile kullanım izni alınmıştır. 


\section{Bulgular}

Bu bölümde araştırmanın amaçları dikkate alınarak sınıf öğretmeni adaylarının ÜOSK ölçeğine verdikleri yanıtlar genel ortalamalar bağlamında, sonra cinsiyet, genel not ortalaması, okul deneyiminde Türkçe dersinde gözlem yapma durumlarına, öğretmenlik uygulamasında Türkçe dersinde uygulama yapma durumlarına yönelik incelenmiş, sonuçlar tablolar hâlinde sunulmuştur. Araştırmanın nitel bulguları kısmında sınıf öğretmeni adayları öğretmenlik uygulaması kapsamında Türkçe dersleri gözlemlenmiş, gözlem verileri tablolar halinde sunulmuştur.

\section{Nicel Boyuttan Elde Edilen Bulgular}

\section{Sınıf Öğretmeni Adaylarının ÜOSK Düzeylerine ilişskin Yapılan Betimsel Analiz Bulguları}

Sınıf öğretmeni adaylarının ÜOSK düzeylerine ilişkin yapılan betimsel analiz sonuçları ise aşağıda Tablo 3'te verilmiştir.

Tablo 3.

Sını Öğretmeni Adaylarının ÜOSK Ölçeğinin Boyutlarına ilişskin Genel Ortalama Değerleri

\begin{tabular}{lccccc}
\hline Boyut & $N$ & Min. & Mak. & $\overline{\boldsymbol{X}}$ & Ss \\
\hline Okumaya hazırlık & 114 & 12 & 25 & 20,09 & 2,77 \\
\hline Okuma esnası & 114 & 8 & 25 & 18,82 & 3,62 \\
\hline Okuma sonrası & 114 & 20 & 35 & 30,98 & 3,44 \\
\hline Okuduğunu değerlendirme & 114 & 16 & 40 & 30,38 & 5,25 \\
\hline ÜOSKÖ Toplam & 114 & 64 & 124 & 100,28 & 12,40 \\
\hline
\end{tabular}

$\mathrm{N}=$ Katılımcı Sayısı, $\overline{\mathrm{X}}=$ Ortalama, Ss= Standart Sapma

Tablo 3'te, 114 sınıf öğretmeni adayının ÜOSK genel ortalamasının $\bar{x}=100,28$, standart sapması ise $s s=12,40$ olduğu görülmektedir. Ölçeğin alt boyutları incelendiğinde okumaya hazırlık boyutunun ortalaması $\bar{x}=20,09$, standart sapması ise $s s=2,77$; okuma esnası boyutunun ortalaması $\bar{x}=18,82$, standart sapması ise $s s=3,62$; okuma sonrası boyutunun ortalaması $\bar{x}=30,98$, standart sapması ise $s s=3,44$; okuduğunu değerlendirme boyutunun ortalaması $\bar{x}=30,38$, standart sapması ise $s s=5,25$ olduğu belirlenmiştir. Sınıf öğretmeni adaylarının ÜOSK düzeylerinde okuma esnası boyutunda en düşük ortalamaya sahip oldukları görülmektedir. Araştırmada ÜOSK normal dağılım gösteren okuma esnası alt boyutunun problem durumlarında belirtilen değişkenlere göre $t$ - Testi ve tek yönlü varyans analizi olan ANOVA sonuçları sunulmuştur.

Sınıf Öğretmeni Adaylarının ÜOSK Düzeylerinin Okuma Esnası Boyutunda Cinsiyet, Öğretmenlik Uygulamasında Türkçe Dersinde Uygulama Yapma ve Okul Deneyiminde Türkçe Dersinde Gözlem Yapma Durumlarına ilişskin T-Testi Bulguları

Sınıf öğretmeni adaylarının cinsiyet, öğretmenlik uygulamasında Türkçe dersinde uygulama yapmalarına ve okul deneyiminde Türkçe dersinde gözlem yapmalarına ilişkin ÜOSK düzeylerinin okuma esnası boyutunda puanlar arasında, anlamlı düzeyde fark olup olmadığını belirlemek için yapılan t-testi bulguları Tablo 4 'te verilmiştir.

Tablo 4.

Sınıf Öğretmeni Adaylarının ÜOSK Düzeylerinin Okuma Esnası Boyutunda Değişkenler Iç̧in T-Testi Sonuçları

\begin{tabular}{|c|c|c|c|c|c|c|c|c|}
\hline $\begin{array}{l}\overline{\bar{\pi}} \\
\overline{\tilde{y}} \\
\bar{y}\end{array}$ & \multicolumn{2}{|l|}{ Değişken } & $N$ & $\bar{X}$ & Ss & $s d$ & $t$ & $p$ \\
\hline \multirow{2}{*}{ 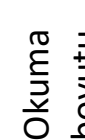 } & \multirow[t]{2}{*}{ Cinsiyet } & Kadın & 94 & 19,14 & & \multirow{2}{*}{112} & 2,10 & \multirow{2}{*}{,038* } \\
\hline & & Erkek & 20 & 17,30 & 3,74 & & 1 & \\
\hline
\end{tabular}


Sınıf Öğretmeni Adaylarının Üstbilişsel Okuma Stratejilerini Kullandırma Düzeyleri: Bir Karma Yöntem Çalışması

\begin{tabular}{|c|c|c|c|c|c|c|c|c|}
\hline \multirow{3}{*}{ 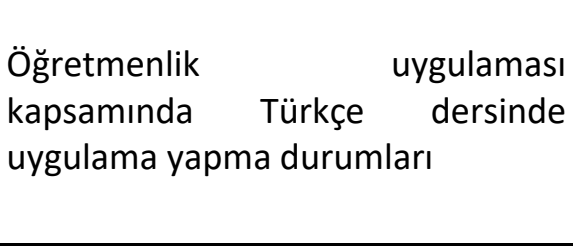 } & & & \multirow{2}{*}{$\begin{array}{l}N \\
57\end{array}$} & $\bar{X}$ & Ss & $s d$ & \multicolumn{2}{|r|}{$p$} \\
\hline & \multicolumn{2}{|l|}{ Evet } & & 18,87 & 3,73 & \multirow{2}{*}{111} & \multirow{2}{*}{ 159, } & \multirow{2}{*}{874} \\
\hline & Hayır & & 56 & 18,76 & 3,57 & & & \\
\hline \multirow{4}{*}{$\begin{array}{l}\text { Okul deneyimi kapsamında Türkçe } \\
\text { dersinde gözlem yapma durumları }\end{array}$} & & $N$ & & $\bar{X}$ & Ss & $s d$ & $t$ & $p$ \\
\hline & Evet & 106 & & 18,62 & 3,66 & \multirow{3}{*}{112} & \multirow{3}{*}{$-2,200$} & \multirow{3}{*}{,030* } \\
\hline & $\begin{array}{l}\text { Hayı } \\
r\end{array}$ & 8 & & 21,50 & 1,41 & & & \\
\hline & & 114 & & & & & & \\
\hline
\end{tabular}

${ }^{*} p<, 05$

Tablo 4 incelendiğinde sınıf öğretmeni adaylarının ÜOSK düzeylerinin okuma esnası boyutu ile öğretmenlik uygulaması kapsamında Türkçe dersinde uygulama yapma durumları arasında anlamlı bir fark olmadığı tespit edilmiştir. Bununla birlikte analizler sonucunda ÜOSK düzeylerinin okuma esnası boyutu ile cinsiyet arasında ( $p=0,038, t=2,101, \bar{X}=19,14, S s=3,53)$ kadınlar lehine anlamlı bir fark olduğu tespit edilmiştir Sınıf öğretmeni adaylarının ÜOSK düzeylerinin okuma esnası boyutu ile okul deneyimi kapsamında Türkçe dersinde gözlem yapma durumları arasında $(p=0,030, t=-2,200, \bar{X}=21,50, S s=1,41)$ gözlem yapmama lehine anlamlı bir fark olduğu tespit edilmiştir.

Sınıf Öğretmeni Adaylarının ÜOSK Düzeylerinin Okuma Esnası Boyutunda Genel Not Ortalamalarına Göre Tek Yönlü Varyans Analizine ilişskin Bulguları

Sınıf öğretmeni adaylarının ÜOSK düzeylerinin okuma esnası boyutunda genel not ortalamalarına göre tek yönlü varyans analizi sonuçları Tablo 5'te verilmiştir.

Tablo 5.

Sınıf Öğretmeni Adaylarının ÜOSK Düzeylerinin Okuma Esnası Boyutunda Genel Not Ortalamalarına Göre ANOVA Sonuçları

\begin{tabular}{|c|c|c|c|c|c|c|c|c|c|c|c|}
\hline$\stackrel{P}{\underline{Z}}$ & $\begin{array}{l}\text { Genel not } \\
\text { ortalaması }\end{array}$ & $N$ & $\bar{X}$ & Ss & $\begin{array}{l}\text { Varyans } \\
\text { Kaynağı }\end{array}$ & $\begin{array}{l}\text { Kareler } \\
\text { Toplamı }\end{array}$ & $s d$ & $\begin{array}{l}\text { Kareler } \\
\text { Ortalaması }\end{array}$ & $F$ & $p$ & Fark \\
\hline วิ & $2,00-2,49$ & 15 & 16,86 & 3,62 & \multirow{3}{*}{$\begin{array}{l}\text { Gruplar } \\
\text { arası }\end{array}$} & \multirow{3}{*}{66,89} & \multirow{3}{*}{3} & \multirow{3}{*}{22,29} & \multirow{5}{*}{1,728} & \multirow{5}{*}{ 166 } & \multirow{5}{*}{---- } \\
\hline$\frac{0}{\bar{n}}$ & $2,50-2,99$ & 44 & 19,04 & 3,52 & & & & & & & \\
\hline$\overbrace{\overparen{n}}^{\pi}$ & $3,00-3,49$ & 49 & 19,20 & 3,38 & & & & & & & \\
\hline$\stackrel{\mathscr{0}}{\mathscr{\sigma}}$ & $3,50-4,00$ & 6 & 19,00 & 5,51 & \multirow[t]{2}{*}{$\begin{array}{l}\text { Gruplar } \\
\text { içi }\end{array}$} & 1419,60 & 110 & \multirow[t]{2}{*}{12,90} & & & \\
\hline$\frac{\bar{z}}{0}$ & Toplam & 114 & 18,82 & 3,62 & & 1486,49 & 113 & & & & \\
\hline
\end{tabular}

Tablo 5'te görüldüğü üzere sınıf öğretmeni adaylarının ÜOSK düzeylerinin okuma esnası boyutu ile genel not ortalaması arasında $(p=0,166, F=1,728)$ anlamlı bir fark olmadığı tespit edilmiştir.

Sınıf Öğretmeni Adaylarının ÜOSK Düzeylerinin Okumaya Hazırlık, Okuma Sonrası, Okumayı Değerlendirme Boyutlarında ve ÜBOSK Toplamında Cinsiyet Değişkenine Göre Mann Whitney U Analizi Bulguları

Sınıf öğretmeni adaylarının ÜOSK düzeylerinin okumaya hazırlık, okuma sonrası, okumayı değerlendirme boyutlarında ve ÜBOSK toplamında cinsiyet değişkenine göre Mann Whitney $U$ sonuçları Tablo 6'da sunulmuştur. 
Tablo 6.

Sınıf Öğretmeni Adaylarının ÜOSK Düzeylerinin Okumaya Hazırlık, Okuma Sonrası ve Okumayı Değerlendirme Boyutlarında Cinsiyet Değişkenine Göre Mann Whitney U Testi Sonuçları

\begin{tabular}{|c|c|c|c|c|c|c|}
\hline Alt Boyutlar & Cinsiyet & $N$ & S.O & $S . T$ & $u$ & $p$ \\
\hline \multirow[t]{2}{*}{ Okumaya hazırlık } & Kadın & 94 & 60,1 & 5678,50 & & \\
\hline & Erkek & 20 & 43,83 & 876,50 & 666,500 &, $040^{*}$ \\
\hline \multirow[t]{2}{*}{ Okuma sonrası } & Kadın & 94 & 60,3 & 5699 & & \\
\hline & Erkek & 20 & 42,80 & 856 & 646,500 &, $028^{*}$ \\
\hline \multirow{2}{*}{$\begin{array}{l}\text { Okumayı } \\
\text { değerlendirme }\end{array}$} & Kadın & 94 & 61,8 & 5741,50 & & \\
\hline & Erkek & 20 & 40,68 & 813,50 & 603,500 &, $012^{*}$ \\
\hline \multirow[t]{2}{*}{ ÜBOSK Toplam } & Kadın & 94 & 61,05 & 5739 & & \\
\hline & Erkek & 20 & 40,80 & 816 & 606,500 &, $013 *$ \\
\hline
\end{tabular}

$\mathrm{N}=$ Katılımcı Sayısı, S.O= Sıra Ortalaması, S.S= Standart Sapma, S.T= Sıra Toplamı, p<0,05*

Tablo 6 incelendiğinde sınıf öğretmeni adaylarının ÜOSK düzeylerinin cinsiyet değişkenine göre okuma hazırlık, okuma sonrası, okumayı değerlendirme ve genel toplam boyutlarında anlamlı bir farka rastlanmıştır. Okumaya hazırlık boyutunda $(p=0,040, u=666,500, S . O=60,41)$ okuma sonrası, boyutunda ( $p=0,028, u=646,500, S .0=60,63$ ) okumayı değerlendirme boyutunda ( $p=0,012, u=603,500$, S.O $=61,08)$ ve genel toplamda $(p=0,013, u=606,500, S . O=61,05)$ kadınlar lehine anlamlı bir farka rastlanmıştır.

Sınıf Öğretmeni Adaylarının ÜOSK Düzeylerinin Okumaya Hazırlık, Okuma Sonrası, Okumayı Değerlendirme Boyutlarında ve ÜBOSK Toplamında Öğretmenlik Uygulamasında Türkçe Dersinde Uygulama Yapmalarına Değişkenine Göre Mann Whitney U Analizi Bulguları

Sınıf öğretmeni adaylarının ÜOSK düzeylerinin okumaya hazırlık, okuma sonrası, okumayı değerlendirme boyutlarında ve ÜBOSK toplamında öğretmenlik uygulamasında Türkçe dersinde uygulama yapmalarına değişkenine göre Mann Whitney U sonuçları Tablo 7 'de sunulmuştur.

Tablo 7.

Sınıf Öğretmeni Adaylarının ÜOSK Düzeylerinin Okumaya Hazırık, Okuma Sonrası ve Okumayı Değerlendirme Boyutlarında Türkçe Dersinde Uygulama Yapmaları Değişkenine Göre Mann Whitney U Testi Sonuçları

\begin{tabular}{|c|c|c|c|c|c|c|}
\hline Alt Boyutlar & \multicolumn{6}{|c|}{$\begin{array}{l}\text { Türkçe dersinde } \\
\text { uygulama }\end{array}$} \\
\hline \multirow[t]{2}{*}{ Okumaya hazırlık } & Evet & 58 & 58,55 & 333750 & \multirow[t]{2}{*}{1507,50} & \multirow[t]{2}{*}{609} \\
\hline & Hayır & 56 & 55,42 & 3103,50 & & \\
\hline \multirow[t]{2}{*}{ Okuma sonrası } & Evet & 58 & 58,07 & 3310 & \multirow[t]{2}{*}{1535} & \multirow[t]{2}{*}{,724 } \\
\hline & Hayır & 56 & 55,91 & 311 & & \\
\hline \multirow[t]{2}{*}{ Okumayı değerlendirme } & Evet & 58 & 59,46 & 3389 & \multirow[t]{2}{*}{1456} & \multirow[t]{2}{*}{,420 } \\
\hline & Hayır & 56 & 54,50 & 3052 & & \\
\hline \multirow[t]{2}{*}{ ÜBOSK Toplam } & Evet & 58 & 58,93 & 3359 & \multirow[t]{2}{*}{1486} & \multirow[t]{2}{*}{, 527} \\
\hline & Hayır & 56 & 55,04 & 3082 & & \\
\hline
\end{tabular}

$\mathrm{N}=$ Katılımcı SayıSı, S.O= Sıra Ortalaması, S.S= Standart Sapma, S.T= Sıra Toplamı, $p<0,05$ 
Sınıf Öğretmeni Adaylarının Üstbilişsel Okuma Stratejilerini Kullandırma Düzeyleri: Bir Karma Yöntem Çalışması

Tablo 7 incelendiğinde sınıf öğretmeni adaylarının ÜOSK düzeylerinin Türkçe dersinde uygulama yapma değişkenine göre okuma hazırıı, okuma sonrası, okumayı değerlendirme ve genel toplam boyutlarında anlamlı bir farka rastlanmamıştır. Okumaya hazırlık boyutunda $(p=0,609$, $u=1507,50)$ okuma sonrası, boyutunda $(p=0,724, u=1535)$ okumayı değerlendirme boyutunda $(p=0,420, u=1456)$ ve genel toplamda $(p=0,527, u=1486)$ anlamlı bir farka rastlanmamıştır.

Sınıf Öğretmeni Adaylarının ÜOSK Düzeylerinin Okumaya Hazırlık, Okuma Sonrası, Okumayı Değerlendirme Boyutlarında ve ÜBOSK Toplamında Okul Deneyiminde Türkçe Dersinde Gözlem Yapmaları Değişkenine Göre Mann Whitney U Analizi Bulguları

Sınıf öğretmeni adaylarının ÜOSK düzeylerinin okumaya hazırlık, okuma sonrası, okumayı değerlendirme boyutlarında ve ÜBOSK toplamında okul deneyiminde Türkçe dersinde gözlem yapmaları değişkenine göre Mann Whitney U sonuçları Tablo 8'de sunulmuştur.

Tablo 8.

Sınıf Öğretmeni Adaylarının ÜOSK Düzeylerinin Okumaya Hazırlık, Okuma Sonrası ve Okumayı Değerlendirme Boyutlarında Türkçe Dersinde Gözlem Yapmaları Değişkenine Göre Mann Whitney U Testi Sonuçları

\begin{tabular}{|c|c|c|c|c|c|c|}
\hline Alt Boyutlar & \multicolumn{4}{|c|}{ Türkçe dersinde } & $\mathrm{u}$ & $p$ \\
\hline \multirow[t]{2}{*}{ Okumaya hazırlık } & Evet & 106 & 56,33 & 5971,50 & \multirow[t]{2}{*}{300,50} & \multirow[t]{2}{*}{ 168 } \\
\hline & Hayır & 8 & 72,94 & 583,50 & & \\
\hline \multirow[t]{2}{*}{ Okuma sonrası } & Evet & 106 & 58,08 & 6157 & \multirow[t]{2}{*}{362} & \multirow[t]{2}{*}{,489 } \\
\hline & Hayır & 8 & 49,75 & 398 & & \\
\hline \multicolumn{2}{|c|}{ Okumayı değerlendirme Evet } & 106 & 56,98 & 6039,50 & \multirow[t]{2}{*}{368,500} & \multirow[t]{2}{*}{,537 } \\
\hline & Hayır & 8 & 64,44 & 515,50 & & \\
\hline \multirow[t]{2}{*}{ ÜBOSK Toplam } & Evet & 106 & 56,66 & 6006,50 & \multirow[t]{2}{*}{335} & \multirow[t]{2}{*}{,323 } \\
\hline & Hayır & 8 & 68,63 & 549 & & \\
\hline
\end{tabular}

$\mathrm{N}=$ Katılımcı Sayısı, S.O= Sıra Ortalaması, S.S= Standart Sapma, S.T= Sıra Toplamı, $p<0,05$

Tablo 8 incelendiğinde sınıf öğretmeni adaylarının ÜOSK düzeylerinin Türkçe dersinde gözlem yapma değişkenine göre okuma hazırlık, okuma sonrası, okumayı değerlendirme ve genel toplam boyutlarında anlamlı bir farka rastlanmamıştır. Okumaya hazırlık boyutunda $(p=0,168, u=300,50)$ okuma sonrası, boyutunda ( $p=0489, u=362$ ) okumayı değerlendirme boyutunda $(p=0,537, u=368,50)$ ve genel toplamda $(p=0,323, u=335)$ anlamlı bir farka rastlanmamıştır.

Sınıf Öğretmeni Adaylarının ÜOSK Düzeylerinin Okumaya Hazırlık, Okuma Sonrası, Okumayı Değerlendirme Boyutlarında ve ÜBOSK Toplamında Genel Not Ortalamalarına Göre Kruskall WallisH Testi Analizi Bulguları

Sınıf öğretmeni adaylarının ÜOSK düzeylerinin okumaya hazırlık, okuma sonrası, okumayı değerlendirme boyutlarında ve ÜBOSK toplamında genel not ortalamalarına göre Kruskall Wallis-H Testi analizi sonuçları Tablo 9'da verilmiştir.

Tablo 9.

Sınıf ögrretmeni adaylarının ÜOSK düzeylerinin okumaya hazırlık, okuma sonrası ve okumayı değerlendirme boyutlarında genel not ortalaması değişkenine göre Kruskall Wallis-H Testi Sonuçları

\begin{tabular}{|c|c|c|c|c|c|c|}
\hline Alt Boyutlar & Genel Not Ortalaması & $\mathrm{N}$ & S.O & $\mathrm{X} 2$ & $p$ & Fark \\
\hline & (A) $2,00-2,49$ & 15 & 30,30 & 13,394 & ,004* & \\
\hline \multirow{4}{*}{ Okumaya hazırlık } & (B) $2,50-2,99$ & 44 & 57,31 & & & $A-B$ \\
\hline & (C) $3,00-3,49$ & 49 & 65,68 & & & $A-C$ \\
\hline & (D) $3,50-4,00$ & 6 & 60,08 & & & \\
\hline & (A) $2,00-2,49$ & 15 & 35,77 & 7,774 & 051 & \\
\hline
\end{tabular}




\begin{tabular}{lcccccc}
\hline Okuma sonrası & (B) $2,50-2,99$ & 44 & 59,10 & & & \\
& (C) $3,00-3,49$ & 49 & 62,06 & & & \\
& (D) $3,50-4,00$ & 6 & 62,83 & & & A-B \\
Okumayı & (A) $2,00-2,49$ & 15 & 25,00 & 17,019 &, $001^{*}$ & A-C \\
değerlendirme & (B) $2,50-2,99$ & 44 & 61,99 & & & \\
& (C) $3,00-3,49$ & 49 & 63,52 & & & A-B \\
ÜBOSK Toplam & (D) $3,50-4,00$ & 6 & 56,67 & & & A-C \\
& (A) $2,00-2,49$ & 15 & 26,27 & 15,851 &, $001^{*}$ & \\
& (B) $2,50-2,99$ & 44 & 60,05 & & & \\
\hline & (C) $3,00-3,49$ & 49 & 64,34 & & & \\
\hline & (D) $3,50-4,00$ & 6 & 61,08 & & & \\
\hline
\end{tabular}

$\mathrm{N}=$ Katılımcı Sayısı, S.O= Sıra Ortalaması, $\mathrm{p}<0,05^{*}$

Tablo 9 incelendiğinde okumaya hazırlık ve okumayı değerlendirme alt boyutlarında ve ÜOSK genel toplamı ile genel not ortalaması arasında anlamlı fark gözlemlenmiştir. Okumaya hazırlık boyutunda 2,00-2,49 genel not ortalaması ile 2,50-2,99 not ortalaması arasında 2,50-2,99 lehine $[p=0,004, x 2=13,394, S .0=57,31]$ anlamlı bir farka rastlanmıştır. Okumayı değerlendirme boyutunda 2,00-2,49 genel not ortalaması ile 2,50-2,99 not ortalaması arasında 2,50-2,99 lehine [ $p=0,001$, x2 $=17,019$, S.O $=61,99]$ anlamlı bir farka rastlanmıştır. ÜBOSK toplam puanının 2,00-2,49 genel not ortalaması ile 2,50-2,99 not ortalaması arasında 2,50-2,99 lehine $[p=0,001, x 2=15,851, S .0=60,05]$ anlamlı bir farka rastlanmıştır. Okumaya hazırlık boyutunda 2,00-2,49 genel not ortalaması ile 3,003,49 not ortalaması arasında 3,00-3,49 lehine $[p=0,004, x 2=13,394,5.0=65,68]$ anlamlı fark gözlemlenmiştir. Okumayı değerlendirme boyutunda 2,00-2,49 genel not ortalaması ile 3,00-3,49 not ortalaması arasında 3,00-3,49 lehine $[p=0,004, x 2=13,394, S .0=63,52]$ anlamlı fark gözlemlenmiştir. ÜBOSK toplam puanın 2,00-2,49 genel not ortalaması ile 3,00-3,49 not ortalaması arasında 3,00-3,49 lehine $[p=0,004, x 2=13,394, S .0=64,34]$ anlamlı fark gözlemlenmiştir.

\section{Nitel Boyuttan Elde Edilen Bulgular}

Bu bölümde araştırmanın amaçları dikkate alınarak ÜOSK ölçeği maddelerinden yararlanılarak oluşturulan gözlem formu ile sınıf öğretmeni adaylarının öğretmenlik uygulaması I kapsamında Türkçe derslerinin gözlemlenmesi ile elde edilen veriler tablolar halinde sunulmuştur.

\section{Sınıf Öğretmeni Adaylarının ÜBOSK Düzeyinin Okumaya Hazırlık Boyutu Kapsamında Gözlem Bulguları}

Sınıf öğretmeni adaylarının üstbilişsel okuma stratejilerini kullandırma düzeyinin okumaya hazırlık boyutu kapsamında gözlem bulguları Tablo 10'da verilmiştir.

Tablo 10.

ÜOSK Düzeyinin Okumaya Hazırlık Boyutu Kapsamında Öğretmen Adaylarının Gözlem Bulguları

$$
\text { Gözlenen Öğretmen Adayı Kodları }
$$

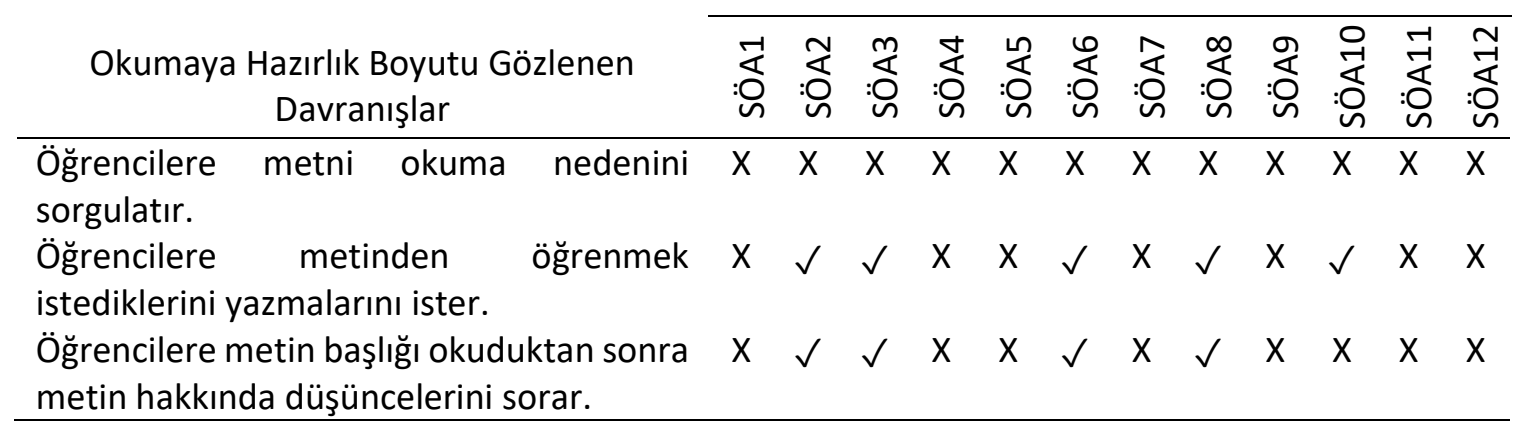


Sınıf Öğretmeni Adaylarının Üstbilişsel Okuma Stratejilerini Kullandırma Düzeyleri: Bir Karma Yöntem Çalışması

\begin{tabular}{|c|c|c|c|c|c|c|c|c|c|c|c|c|}
\hline $\begin{array}{l}\text { Öğrenciler metni okurken, durdurup } \\
\text { metnin nasıl gelişeceğini tahmin } \\
\text { etmelerini ister. }\end{array}$ & $X$ & $\checkmark$ & $X$ & $x$ & $x$ & $\checkmark$ & $x$ & $\checkmark$ & $X$ & $\checkmark$ & $X$ & $x$ \\
\hline $\begin{array}{l}\text { Öğrenciler metni okurken, durdurup } \\
\text { metnin nasıl sonuçlanacağını tahmin } \\
\text { etmelerini ister. }\end{array}$ & $x$ & $\sqrt{ }$ & $X$ & $X$ & $X$ & $\checkmark$ & $X$ & $\checkmark$ & $X$ & $\checkmark$ & $X$ & $X$ \\
\hline
\end{tabular}

* "Gözlendi" ( $\sqrt{ }$ ) ve "Gözlenmedi" (X)

Tablo 10’da görüldüğü üzere ÜOSK düzeylerinin okumaya hazırlık boyutunda SÖA2, SÖA6, SÖA8 kodlu sınıf öğretmeni adaylarının öğretmenlik uygulaması kapsamında Türkçe dersinde öğrencileri okuma sürecine daha çok hazırladıkları gözlemlenmiştir. Buna rağmen SÖA1, SÖA4, SÖA5, SÖA7, SÖA9, SÖA11, SÖA12 kodlu öğretmen adaylarının üstbilişsel okuma stratejilerini kullandırmada öğrencileri okumaya hazırlama bağlamında gözlenen davranışları olmamıştır. Diğer önemli nokta sınıf öğretmeni adaylarının tamamının Türkçe dersinde öğrencilere okuma metnini sorgulatmadığı gözlemlenmiştir.

\section{Sınıf Öğretmeni Adaylarının ÜOSK Düzeyinin Okuma Esnası Boyutu Kapsamında Gözlem Bulguları}

Sınıf öğretmeni adaylarının ÜOSK düzeyinin okuma esnası boyutu kapsamında gözlem bulguları Tablo 11'de verilmiştir.

Tablo 11.

ÜOSK Düzeyinin Okuma Esnası Boyutu Kapsamında Öğretmen Adaylarının Gözlem Bulguları

$$
\text { Gözlenen Öğretmen Adayı Kodları }
$$

\begin{tabular}{|c|c|c|c|c|c|c|c|c|c|c|c|c|}
\hline $\begin{array}{c}\text { Okuma Esnası Boyutu Gözlenen } \\
\text { Davranışlar }\end{array}$ & : & : & : & : 蒙 & : ֻ & : ¿ & : 这 & 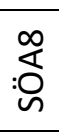 & : & : & : & : \\
\hline $\begin{array}{l}\text { Öğrencilere verilen } \\
\text { içinde gelimelerin } \\
\text { etmebilecek olanları } \\
\text { etmelerini ister. }\end{array}$ & $X$ & $\checkmark$ & $X$ & $x$ & $x$ & $\checkmark$ & $X$ & $\checkmark$ & $X$ & $\checkmark$ & $X$ & $x$ \\
\hline $\begin{array}{l}\text { Öğrencilerden okudukları kısma kadar olan } \\
\text { bölümlerde (tablo, çizelge, hikâye haritalar } \\
\text { vb.) kullanmalarını ister. }\end{array}$ & $x$ & $x$ & $x$ & $x$ & $x$ & $x$ & $x$ & $x$ & $x$ & $x$ & $x$ & $x$ \\
\hline $\begin{array}{l}\text { Öğrencilerden metinde anlamadıkları } \\
\text { kelime ya da kavramları metnin devamında } \\
\text { aramalarını ister. }\end{array}$ & $x$ & $x$ & $x$ & $x$ & $x$ & $x$ & $x$ & $x$ & $x$ & $x$ & $x$ & $x$ \\
\hline $\begin{array}{l}\text { Öğrencilerden okuma süresince neden- } \\
\text { sonuç ilişkisi kurmalarını ister. }\end{array}$ & $x$ & $\checkmark$ & $x$ & $\checkmark$ & $x$ & $\checkmark$ & $x$ & $\checkmark$ & $x$ & $x$ & $x$ & $x$ \\
\hline $\begin{array}{l}\text { Öğrencilerden metindeki durum-kavram- } \\
\text { nesne-olay arasında var olan ilişkileri } \\
\text { belirlemeleri ister. }\end{array}$ & $x$ & $x$ & $x$ & $x$ & $x$ & $x$ & $x$ & $x$ & $x$ & $x$ & $x$ & $x$ \\
\hline
\end{tabular}

* "Gözlendi" ( $\checkmark$ ) ve "Gözlenmedi" $(X)$

Tablo 11 incelendiğinde ÜOSK düzeylerinin okuma esnası boyutunda sınıf öğretmeni adaylarının tamamının öğrencilerden okudukları bölümlerde (tablo, çizelge, hikâye haritalar vb.) kullanmalarını istemedikleri, öğrencilerin anlamadıkları kelimeleri metnin devamında bulmalarını istemedikleri ve öğrencilerden metindeki durum-kavram-olay arasındaki ilişkileri belirlemelerini istemedikleri gözlemlenmiştir. Bununla birlikte SÖA2, SÖA4, SÖA6, SÖA8 kodlu öğretmen adaylarının okuma esnasında öğrencilere metin ile ilgili neden-sonuç ilişkisi kurmalarına imkân sağladıkları gözlemlenmiştir. Sınıf öğretmeni adaylarının ÜOSK noktasında en çok okuma esnasında zorluk yaşadığı görülmektedir. Öğretmen adaylarının özellikle bu boyutta öğrencilerin ÜOSK sağlayamamasında, ders zamanının yetmeyeceği kaygısı taşıyarak, hızlı şekilde okuma esnası süreci geçtikleri düşünülmektedir. 
Sınıf Öğretmeni Adaylarının ÜOSK Düzeyinin Okuma Sonrası Boyutu Kapsamında Gözlem Bulguları

Sınıf öğretmeni adaylarının ÜOSK düzeyinin okuma sonrası boyutu kapsamında gözlem bulguları Tablo 12'de verilmiştir.

Tablo 12.

ÜOSK Düzeyinin Okuma Sonrası Boyutu Kapsamında Öğretmen Adaylarının Gözlem Bulguları

Gözlenen Öğretmen Adayı Kodları

Okuma Sonrası Boyutu Gözlenen

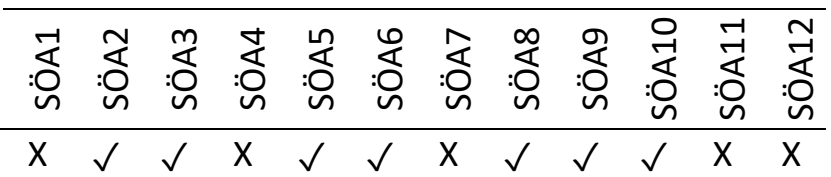

Davranışlar

Öğrencilerden metinde geçen bilmedikleri

kelimelerin altlarını çizmelerini ister.

Öğrencilerden metnin ana fikrini $\begin{array}{lllllllllllll}\checkmark & \checkmark & X & X & X & \checkmark & X & \checkmark & X & \checkmark & X & X\end{array}$

belirtmelerini ister.

Öğrencilerden metne yardımcı fikirleri (yan $\begin{array}{lllllllllllll} & X & X & X & X & X & X & X & X & X & X & X & X\end{array}$

fikirleri) bulmalarını ister.

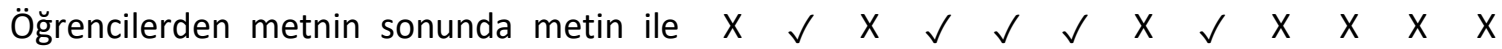

ilgili düşüncelerini ifade etmelerini ister.

Öğrencilere okuma sonunda metinden ne $\quad \begin{array}{lllllllllllll} & X & \checkmark & X & X & X & \checkmark & X & \checkmark & X & \checkmark & \checkmark & \checkmark\end{array}$

öğrendiklerini sorar.

Öğrencilerden metne uygun başlıklar $\quad X \quad \begin{array}{lllllllllll} & X & X & X & \checkmark & X & \checkmark & X & \checkmark & X & X\end{array}$

önermelerini ister.

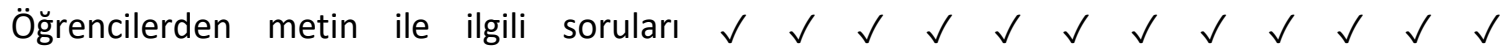
cevaplamalarını ister.

* "Gözlendi" $(\checkmark)$ ve "Gözlenmedi" $(X)$

Tablo 12 'de incelendiğinde ÜOSK düzeylerinin okuma sonrası boyutunda sınıf öğretmeni adaylarının tamamının öğrencilerden metin ile ilgili soruları cevaplamalarını istedikleri gözlemlenmiştir. Buna karşın sınıf öğretmeni adaylarının tamamı metne yardımcı fikirleri (yan fikirleri) bulmaları öğrencilerden istemediği gözlemlenmiştir. SÖA2 ve SÖA6 kodlu öğretmen adaylarının okuma sonrasında öğrencilerin üstbilişsel okuma stratejilerini kullandırmada daha etkin oldukları gözlemlenmiştir.

\section{Sınıf Öğretmeni Adaylarının ÜOSK Düzeyinin Okumayı Değerlendirme Boyutu Kapsamında Gözlem Bulguları}

Sınıf öğretmeni adaylarının ÜOSK düzeyinin okumayı değerlendirme boyutu kapsamında gözlem bulguları Tablo 13' de verilmiştir.

Tablo 13.

ÜOSK Düzeyinin Okumayı değerlendirme Boyutu Kapsamında Öğretmen Adaylarının Gözlem Bulguları

Gözlenen Öğretmen Adayı Kodları

Okumayı Değerlendirme Boyutu Gözlenen

Davranışlar

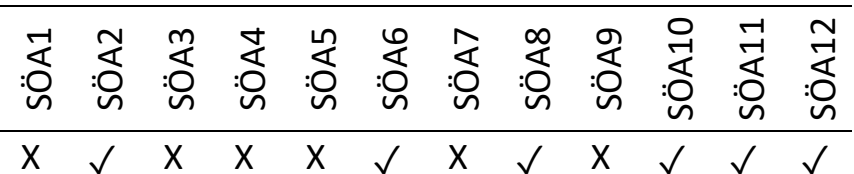

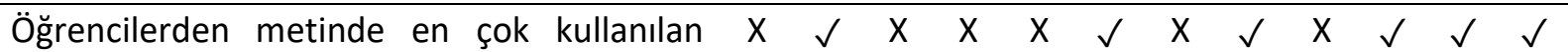

kelimeleri belirlemelerini ister. 


\begin{tabular}{|c|c|c|c|c|c|c|c|c|c|c|c|c|}
\hline $\begin{array}{l}\text { Öğrencilerden metnin sonuna ilişkin } \\
\text { tahminleri ile gerçek sonu karşılaştırmalarını } \\
\text { ister. }\end{array}$ & $X$ & $x$ & $\checkmark$ & $x$ & $x$ & $\checkmark$ & $x$ & $x$ & $X$ & $X$ & $x$ & $x$ \\
\hline $\begin{array}{l}\text { Öğrencilerden okuduklarının kendilerine ne } \\
\text { katkı sağladıklarını değerlendirmelerini ister. }\end{array}$ & $x$ & $x$ & $x$ & $x$ & $x$ & $x$ & $x$ & $x$ & $x$ & $x$ & $x$ & $x$ \\
\hline $\begin{array}{l}\text { Öğrencilerden okuma sonrası önceki ve yeni } \\
\text { bilgilerini tartışmalarını ister. }\end{array}$ & $x$ & $x$ & $x$ & $x$ & $x$ & $x$ & $x$ & $x$ & $x$ & $x$ & $x$ & $x$ \\
\hline $\begin{array}{l}\text { Öğrencilerden öğrenme günlüğü tutmalarını } \\
\text { ister. }\end{array}$ & $x$ & $x$ & $x$ & $x$ & $x$ & $x$ & $x$ & $x$ & $x$ & $x$ & $x$ & $x$ \\
\hline Öğrencilerden metinde yer alan & $x$ & $x$ & $x$ & $x$ & $x$ & $x$ & $x$ & $x$ & $x$ & $x$ & $x$ & $x$ \\
\hline $\begin{array}{l}\text { karakterleri/durumları dramatize etmelerini } \\
\text { ister. }\end{array}$ & & & & & & & & & & & & \\
\hline $\begin{array}{l}\text { Öğrencilerden metinde } \\
\text { nerelerde küğrendiklerini } \\
\text { ister. }\end{array}$ & $x$ & $x$ & $x$ & $x$ & $x$ & $x$ & $x$ & $x$ & $x$ & $x$ & $x$ & $x$ \\
\hline $\begin{array}{l}\text { Öğrencilere metni kendilerinin yazsaydı hangi } \\
\text { kısımları değiştirmek istediklerini sorar. }\end{array}$ & $x$ & $\checkmark$ & $\checkmark$ & $x$ & $x$ & $\checkmark$ & $x$ & $\checkmark$ & $x$ & $x$ & $x$ & $x$ \\
\hline
\end{tabular}

* "Gözlendi" $(\checkmark)$ ve "Gözlenmedi" (X)

Tablo 13' de görüldüğü üzere ÜOSK düzeylerinin okumayı değerlendirme boyutunda sınıf öğretmeni adaylarının çok etkin olmadıkları gözlemlenmiştir. Sınıf öğretmeni adaylarının tamamının öğrencilerden okuma sonrası önceki ve yeni bilgilerini karşılaştırıp, tartışma yapmalarını istemedikleri; metinde yeni öğrendiklerini nerede ve nasıl kullanacaklarını değerlendirmeleri konusunda öğrencileri yönlendirmedikleri; öğrencilerin metinde okuduklarının onlara ne kazandırdığı konusunda değerlendirme yapmalarına imkân tanımadıkları gözlemlenmiştir.

\section{Tartışma ve Sonuç}

Araştırmada sınıf öğretmeni adaylarının ÜOSK düzeyleri okumaya hazırlık, okuma esnası, okuma sonrası ve okumayı değerlendirme boyutlarında çeşitli değişkenlere göre incelenmiştir. Sınıf öğretmeni adaylarının üstbilişsel okuma stratejilerini kullandırma düzeylerinde okuma esnası boyutunda en düşük ortalamaya sahip oldukları görülmektedir.

Üstbilişsel okumada önemli olan bireylerin okumalarını nitelikli şekilde anlayarak, yorumlayarak, değerlendirerek, özümseyerek yapmaları ve okuduklarından sonuçlar çıkarmalarıdır (Akın ve Çeçen, 2014; Tosun ve Irak, 2008). Bu bağlamda öğretmenlerin öğrenciler için okuma temel becerisinde kullandıkları stratejiler okuduğunu anlama için oldukça önemlidir (Karatay, 2010). Üstbilişsel okuma bireylerin yeni ve eski bilgilerini ilişkilendirme, yaratıcı düşünmeyi geliştirme ve yazma becerisini desteklemeyi sağlar (Perfetti, 2007). Öğretmen yetiştirmede amaç hizmet öncesinde öğretmen adaylarının nitelikli öğretim faaliyetini sınıflarında hayata uygulayacak donanıma sahip olmalarını sağlamaktır. Alan yazında öğrenciye üst bilişini tüm becerilerde nasıl kullanacağını kazandırmada öğretmenlerin önemli bir rolü olduğu, sınıf öğretmenlerinin Türkçe dersinde üstbilişsel okuma stratejilerini kullandırmaya ilişkin olumlu görüşlere sahip oldukları tespit edilmiştir (Çakıroğlu, 2007). Sınıf öğretmenleri ile yapılan başka bir çalışmada da ÜOSK konusunda öğretmenlerin zenginlik sağlayamadıkları; stratejilerin kullanıma ilişkin farkındalığa sahip olmalarına rağmen ders süresinin yetmemesinden, sınıf mevcutlarının fazlalığından kaynaklanan nedenlerle çok fazla uygulamaya geçiremediklerini belirtilmiştir (İnce ve Duran, 2013). Konuyla ilgili literatür incelendiğinde öğretmenlerin üstbilişsel okuma stratejilerini kullanabilme düzeylerinin değişkenlik gösterdiği gözlenmektedir. Çalışmada gözlem sonuçları bağlamında sınıf öğretmeni adaylarının Türkçe dersi içerisinde üstbilişsel okuma stratejilerini etkin şekilde kullanmadıkları; özellikle okuma esnası sırasında dersin bitmesi ve metin okuma sürecinin yarıda kalması kaygısıyla hızlıca geçildiği gözlemlenmiştir. Aynı zamanda okumayı değerlendirme kısmında öğretmen adaylarının teneffüs zilinin çalması, Türkçe dersinin sona ermesi nedeniyle tam olarak etkin şekilde gerçekleştiremedikleri gözlemlenmiştir. 
Araştırmada sınıf öğretmenlerinin ÜOSK düzeylerinin cinsiyet değişkeni bağlamında irdelenmesinde; okumaya hazırlık, okuma esnası, okuma sonrası ve okumayı değerlendirme boyutlarında cinsiyete göre kadınlar lehine anlamlı fark gözlemlenmiştir. Araştırmada sınıf öğretmeni adaylarının Türkçe dersinde ÜOSK durumlarına ilişkin sınıf içi gözlemlerde de kadın öğretmen adaylarının tüm alt boyutlarda daha etkin şekilde stratejileri kullandıkları gözlemlenmiştir. Alan yazında farklı branşlarda öğretmen adaylarıyla yapılan çalışmalarda da kadın öğretmen adaylarının erkek öğretmen adaylarına göre üstbilişsel stratejileri daha fazla kullandıkları sonucu araştırma bulgularıyla örtüşmektedir (Ateş, 2013; Baykara, 2011; Demir ve Özmen, 2011; Topuzkanamış ve Maltepe, 2010). Bu çalışmalardaki sonuçların aksine Karatay (2010) tarafından yapılan çalışmada üstbilişsel okuma stratejilerde erkeklerin lehine anlamlı farklılıklar olduğu sonucuna ulaşmıştır. Alan yazında Sulak ve Behriz (2018) tarafından gerçekleştirilen çalışmada sınıf öğretmenlerinin Türkçe derslerinde ÜOSK düzeylerinin cinsiyet değişkenine göre anlamlı bir fark göstermediği tespit edilmiştir. Bu bağlamda birçok çalışmada hem öğretmenlerin hem de öğretmen adaylarının üstbilişsel okuma stratejilerini kullandırmada cinsiyet değişkenine göre farklılık gözlemlenmediği görülmektedir (Aydın ve Coşkun, 2011; Baykara, 2011; Brantmeier, 2003; Dilci ve Kaya, 2012; Erdem, 2012; Mendoza-Denton ve Ayduk, 2015; Özdemir, 2018; Özsoy ve Günindi, 2011; Phakiti, 2003)

Araştırmada sınıf öğretmeni adaylarının genel not ortalamaları değişkeni ile ÜBOSK düzeylerinin okumaya hazırlık, okuma sonrası, okumayı değerlendirme boyutlarında anlamlı farklılık gözlemlenmiştir. Öğretmen adaylarının not ortalamaları arttıkça Türkçe dersinde ÜBOSK düzeyleri okuma esnası dışında tüm boyutlarda fark yaratmıştır.

Araştırmada sınıf öğretmeni adaylarının okul deneyimi kapsamında Türkçe dersinde gözlem yapma durumları okuma esnası boyutunda fark yaratmıştır. Araştırmanın gözlem sonuçlarında ise okuma esnası durumunda üstbilişsel stratejileri kullandırmanın tüm öğretmen adayları tarafından etkin şekilde hayata geçirilemediği gözlemlenmiştir. Bu bağlamda okuma esnası boyutuna ilişkin okul deneyimi kapsamında sınıf öğretmenlerinin kendilerinin yapmış olduğu gözlemlerin fark yaratması durumu, sınıf içinde kendilerinin bu boyutu aktif kılmasına etken olamamıştır.

Araştırmada sınıf öğretmeni adaylarının öğretmenlik uygulaması kapsamında Türkçe dersinde ÜBOSK düzeylerinde tüm boyutlarda anlamlı bir fark tespit edilmemiştir. Bu noktada öğretmen adayların hizmet öncesi dönemde sınıf içinde Türkçe dersinde ÜBOSK düzeylerine öğretmenlik uygulaması dersinin bir etkisi olmadığı söylenebilir. Araştırmanın gözlem sonuçları ele alındığında ise sınıf öğretmeni adaylarının okumaya hazırlık, okuma esnası, okuma sonrası ve okumayı değerlendirme boyutlarında aktif şekilde bu stratejileri ders saatinin az olması, sınıfların kalabalık olması, derste etkili zaman yönetiminin yapılamaması, sınıf yönetiminden kaynaklanan bazı nedenlerden dolayı hayata geçiremedikleri gözlemlenmiştir. Bu bulgu Girgin ve Şahin (2019) tarafından sınıf öğretmeni adaylarının öğretmenlik uygulaması dersi kapsamındaki etkinlik hazırlama ve uygulama süreçlerinin incelenmesi çalışmasında da benzer bir gözlem bulgusu söz konusudur. Çalışmada bir diğer gözlem bulgusu ise Türkçe dersi kazanımlarında da yer alan yazma temel becerisinin hayata geçirilmesinde özellikle yansıtıcı düşünme bağlamında önemli bir rolü olan öğrenme günlüklerinin öğrenciler tarafından tutulması konusunda tüm öğretmen adaylarının yönlendirme yapmadığı gözlemlenmiştir. Diğer önemli bir bulgu ise sınıf öğretmeni adaylarının lisans programlarında gerek meslek bilgisi dersi gerekse seçmeli dersler havuzundan almış olduğu drama derslerinde öğrendiklerini kullanmadıkları; öğrencilerden metinde geçen karakterleri, olayları canlandırmalarını, dramatize etmelerini istemedikleri gözlemlenmiştir. Özellikle okuma sonrası okumayı değerlendirmenin ne kadar önemli olduğu düşünülürse, öğretmen adaylarının birçoğunun okumayı değerlendirmede öğrencilere üstbilişsel okuma stratejilerini kullandırmadıkları gözlemlenmiştir. Bu noktada hem öğretmen adaylarının bu stratejileri nasıl kullandıracaklarına ilişkin yetkinliklerinin tam olarak olmaması hem de öğretmen adaylarının zaman yönetimi açısından gereken becerilere sahip olmamalarının (teneffüs zilinin çalması, Türkçe dersinin bitmesi) etken olduğu düşünülmektedir.

Araştırma sonuçları genel olarak değerlendirildiğinde öğretmen adaylarının not ortalaması ve cinsiyet gibi bireysel özelliklerinin ÜBOSK üzerinde fark yarattığı; öğretmen adaylarının Türkçe dersinde gözlem yapmalarının bu stratejileri kullandırmada etkili olduğu ama Türkçe dersinde uygulama yapmanın bu stratejileri etkin kılmada fark yaratmadığı sonucuna ulaşılmıştır. Öğretmen adaylarının 
sınıf içinde üstbilişsel stratejileri kullandırma noktasında da özellikle okuma esnası ve okumayı değerlendirme kııımları daha çok olmakla birlikte genel olarak da bu stratejileri kullandırmaya yönelik yeterli davranış sergileyemedikleri gözlemlenmiştir. Alan yazında birçok çalışma öğretmenlerin ve öğretmen adaylarının çeşitli değişkenler bağlamında üstbilişsel okuma stratejilerini kullandırmada etikliğini vurgulamıştır (Kuzu, 2004; Williams ve Hall,2010). Araştırmada elde edilen sonuçlara dayalı olarak şu öneriler getirilebilir:

1.Öğretmen adaylarının üstbilişsel okuma stratejilerini etkin şekilde kullandırmaları için hizmet öncesinde meslek bilgisi dersleri kapsamında uygulamalar içeren çeşitli eğitimler verilebilir.

2.Öğretmen adaylarının üstbilişsel okuma stratejilerini kullandırma düzeylerinin çeşitli değişkenler bağlamında deneysel çalışma deseninde incelenmesi yapılabilir.

3.Öğretmen adaylarının üstbilişsel okuma stratejilerini kullandırma bağlamında nitel araştırma desenleri ile desteklenmiş araştırmalar gerçekleştirilebilir. Bu bağlamda öğretmen adayları ile görüşmeler gerçekleştirilebilir ya da bu stratejilerin nitelikli şekilde kullanılması için ders içindeki deneyimlerinden oluşan günlükleri incelenebilir.

4.Üstbilişsel okuma stratejilerinin kullanılmasına yönelik teknikler geliştirilerek öğretmen yetiştirmede öğretim tasarımları geliştirilebilir.

5.Üstbilişsel okuma stratejilerinin kullandırılması bağlamında öğretmen yetiştirme programları odağında lisans düzeyindeki araştırmalar yaygınlaştırılabilir.

\section{Kaynaklar}

Akın, E. ve Çeçen, M. A. (2014). Ortaokul öğrencilerinin okuma stratejileri üstbilişsel farkındalık düzeylerinin değerlendirilmesi (muş-bulanık örneği). Electronic Turkish Studies, 9(8).

Alexander, P. A. \& Jetton, T. L. (2000). Learning from text: A multidimensional and developmental perspective.

Almasi, J. F. (2003). Teaching strategic reading processes. New York, NY: Guilford.

Anastasiou, D. \& Griva, E. (2009). Awareness of reading strategy use and reading comprehension among poor and good readers. Elementary Education Online, 8(2).

Anderson, N. J. (2012). Reading instruction. The Cambridge guide to pedagogy and practice in second language teaching, 218-225.

Andreassen, R. \& Bråten, I. (2011). Implementation and effects of explicit reading comprehension instruction in fifth-grade classrooms. Learning and Instruction, 21(4), 520-537.

Arastaman G., Öztürk Fidan I. ve Fidan T.(2018). Nitel araştırmada geçerlik ve güvenirlik: kuramsal bir inceleme. YYü Eğitim Fakültesi Dergisi (YYU Journal of Education Faculty), 15(1), 37-75.

Artelt, C., Schiefele, U. \& Schneider, W. (2001). Predictors of reading literacy. European Journal of Psychology of Education, 16(3), 363-383.

Artelt, C. \& Schneider, W. (2015). Cross-country generalizability of the role of metacognitive knowledge in students' strategy use and reading competence. Teachers College Record.

Ataalkın, A. N. (2012). Üst bilişsel öğretim stratejilerine dayalı öğretimin öğrencilerin üst bilişsel farkındalık ve becerisine, akademik başarı ile tutumuna etkisi. Yayımlanmamış yüksek lisans tezi). Akdeniz Üniversitesi Sosyal Bilimler Enstitüsü, Antalya.

Ates, S. (2013). Eleştirel okuma ve bir beceri olarak öğretimi. Turkish journal of education, 2(3), 40-49.

Aydın, F. ve Coşkun, M. (2011). Geography teacher candidates' metacognitive awareness levels: A case study from Turkey. Archives of Applied Science Research, 3(2), 551-557.

Azevedo, R. \& Aleven, V. (2013). Metacognition and learning technologies: An overview of current interdisciplinary research. In International handbook of metacognition and learning technologies (pp. 1-16). Springer, New York, NY.

Baker, L., Dreher, M. J. \& Guthrie, J. T. (Eds.). (2000). Engaging young readers: Promoting achievement and motivation. Guilford Press.

Basaran, M. (2013). Reading fluency as an indicator of reading comprehension. Educational Sciences: Theory and Practice, 13(4), 2287-2290.

Baykara, K. (2011). Öğretmen adaylarının bilişötesi öğrenme stratejileri ile öğretmen yeterlik algıları üzerine bir çalışma. Hacettepe Üniversitesi Eğitim Fakültesi Dergisi, 40(40), 80-92. 
Best, J. W. \& Kahn, J. V. (2017). Eğitimde araştırma yöntemleri. M. Durmuş̧̧elebi (Çev.), O. Köksal (Çev. Ed.). Konya: Dizgi Ofset.

Block, C. C. \& Israel, S. E. (2005). Reading first and beyond: The complete guide for teachers and literacy coaches. Corwin Press.

Block, C. C. ve Pressley, M. (2007). Best Practices in Teaching Comprehension.

Boghian, I. (2016). Metacognitive learning strategies in teaching English as a foreign language. Journal of Innovation in Psychology, Education and Didactics, 20(1), 53-62.

Brantmeier, C. (2003). Beyond linguistic knowledge: Individual differences in second language reading. Foreign Language Annals, 36(1), 33-43.

Büyüköztürk, S., Kılıc-Cakmak, E., Akgün, O. E., Karadeniz, S. ve Demirel, F.(2011). Bilimsel Arastirma Yontemleri [Scientific Research Methods]. Ankara: Pegem A Yayıncılık.

Cain, K., Oakhill, J. \& Bryant, P. (2004). Children's reading comprehension ability: Concurrent prediction by working memory, verbal ability, and component skills. Journal of educational psychology, 96(1), 31.

Cano, F., García, Á., Justicia, F. \& García-Berbén, A. B. (2014). Learning approaches and reading comprehension: The role of student questioning and prior knowledge. Revista de Psicodidáctica, 19(2), 247-265.

Cantrell, S. C., Almasi, J. F., Carter, J. C., Rintamaa, M. \& Madden, A. (2010). The impact of a strategybased intervention on the comprehension and strategy use of struggling adolescent readers. Journal of Educational Psychology, 102(2), 257.

Cohen, L., Manion, L. \& Morrison, K. (2005). Research methods in education. British Library Cataloguing in Publication Data. Master e-book ISBN.

Creswell, J. W. (2009). Research design: Qualitative and mixed methods approaches. London and Thousand Oaks: Sage Publications.

Creswell, J. W. \& Clark, V. L. P. (2017). Designing and conducting mixed methods research. Sage publications.

Creswell, J. W. \& Plano Clark, V. L. (2011). Choosing a mixed methods design. Designing and conducting mixed methods research, 2, 53-106.

Cromley, J. G., Snyder-Hogan, L. E. \& Luciw-Dubas, U. A. (2010). Reading comprehension of scientific text: A domain-specific test of the direct and inferential mediation model of reading comprehension. Journal of Educational Psychology, 102(3), 687.

Cromley, J. G. \& Azevedo, R. (2007). Testing and refining the direct and inferential mediation model of reading comprehension. Journal of Educational Psychology, 99(2), 311.

Curwen, M. S., Miller, R. G., White-Smith, K. A. \& Calfee, R. C. (2010). Increasing teachers' metacognition develops students' higher learning during content area literacy instruction: Findings from the read-write cycle project.

Çakıroğlu, A. (2007). Üstbilişsel strateji kullanımının okuduğunu anlama düzeyi düşük öğrencilerde erişi artırımına etkisi. Yayımlanmamış doktora tezi, Gazi Üniversitesi, Ankara.

Çeçen, M. A. ve Alver, M. (2011). Türkçe öğretmeni adaylarının üstbilişsel okuma stratejilerini kullanma düzeyleri (Giresun Üniversitesi örneği). Karadeniz Sosyal Bilimler Dergisi, 3(5), 39-56.

Demir, Ö. ve Özmen, S. K. (2011). Üniversite öğrencilerinin üst biliş düzeylerinin çeşitli değişkenler açısından incelenmesi. Çukurova Üniversitesi Sosyal Bilimler Enstitüsü Dergisi, 20(3), 145-160.

Dilci, T. ve Kaya, S. (2012). Examination of meta-cognitive awareness levels of class teachers teaching 4 th and 5th grades in terms of various variables. SDU Faculty of Arts and Sciences Journal of Social Sciences, 27, 247-267.

Dinner, L. R. (2009). Analysis of the metacognitive and affective components of learning on reading achievement of striving readers with and without a reading disability (Doctoral dissertation, University of Kansas).

Dole, J. \& Nokes, J. J. Drits, D.(2009).Cognitive strategy instruction. Handbook of Research on Reading Comprehension. NY: Routledge.

Duffy, G. (2005). Metacognition and the development of reading teachers. Metacognition and literacy learning, 299-314. 
Edmonds, M. S., Vaughn, S., Wexler, J., Reutebuch, C., Cable, A., Tackett, K. K. \& Schnakenberg, J. W. (2009). A synthesis of reading interventions and effects on reading comprehension outcomes for older struggling readers. Review of educational research, 79(1), 262-300.

Edwards, A. J., Weinstein, C. E., Goetz, E. T. \& Alexander, P. A. (2014). Learning and study strategies: Issues in assessment, instruction, and evaluation. Elsevier.

Ekiz, D. (2003). Introduction to research methods in education. Ankara: Ani Yayincilik.

Erdem, C. (2012). Türk dili ve edebiyatı öğretmen adaylarının okuma stratejilerini kullanma düzeyleri. Uluslararası Türkçe Edebiyat Kültür Eğitim (TEKE) Dergisi, 1(4), 162-186.

Flavell, J. H. (1979). Metacognition and cognitive monitoring: A new area of cognitive-developmental inquiry. American psychologist, 34(10), 906.

Fuchs, L. S., Fuchs, D., Hosp, M. K. \& Jenkins, J. R. (2001). Oral reading fluency as an indicator of reading competence: A theoretical, empirical, and historical analysis. Scientific studies of reading, 5(3), 239-256.

Girgin, D. ve Şahin, Ç. (2019). Sınıf Öğretmeni Adaylarının Öğretmenlik Uygulaması Dersi Kapsamındaki Etkinlik Hazırlama ve Uygulama Süreçlerinin Incelenmesi. Gazi University Journal of Gazi Educational Faculty (GUJGEF), 39(3).

Graham, S. J. (2003). Learners' metacognitive beliefs: A Modern Foreign Languages case study. Research in Education, 70(1), 9-20.

Hartman, H. J. (Ed.). (2001). Metacognition in learning and instruction: Theory, research and practice (Vol. 19). Springer Science \& Business Media.

Houtveen, A. A. M. \& Van de Grift, W. J. C. M. (2007). Effects of metacognitive strategy instruction and instruction time on reading comprehension. School Effectiveness and School Improvement, 18(2), 173-190.

Irak, M. ve Tosun, A. (2008). Exploring the role of metacognition in obsessive-compulsive and anxiety symptoms. Journal of anxiety disorders, 22(8), 1316-1325.

Israel, S. E. (2007). Using Metacognitive Assessments to Create Individualized Reading Instruction. International Reading Association. 800 Barksdale Road, PO Box 8139, Newark, DE 19714-8139.

Ivankova, N. V.\& Kawamura, Y. (2010). Emerging trends in the utilization of integrated designs in the social, behavioral, and health sciences. Sage handbook of mixed methods in social and behavioral research, 2, 581-611.

Iwai, Y. (2011). The effects of metacognitive reading strategies: Pedagogical implications for EFL/ESL teachers. The Reading Matrix 11 (2), 150, 159.

Ince, Y. ve Duran, E. (2013). Sınıf öğretmenlerinin okuduğunu anlama stratejilerine yönelik görüşleri ve kullanma düzeyleri, Okuma Yazma Eğitimi Araştırmaları, 1(1), 9-19.

Johnson, R. B. \& Christensen, L. (2019). Educational research: Quantitative, qualitative, and mixed approaches. SAGE Publications, Incorporated.

Karakelle, S. ve Saraç, S. (2010). Üst biliş hakkında bir gözden geçirme: Üstbiliş çalışmaları mı yoksa üst bilişsel yaklaşım mı?. Türk Psikoloji Yazıları, 13(26), 45-60.

Karasar, N. (2014). Bilimsel araştırma yöntemi (24. Basım). Ankara: Nobel Yayın Dağıtım.

Karatay, H. (2010). İlköğretim öğrencilerinin okuduğunu kavrama ile ilgili bilişsel farkındalıkları. Journal of Türklük Bilimi Araştırmaları, 15(27).

Khezrlou, S. (2012). The relationship between cognitive and metacognitive strategies, age, and level of education. The Reading Matrix, 12(1).

Klingner, J. K., Urbach, J., Golos, D., Brownell, M. \& Menon, S. (2010). Teaching reading in the 21st century: A glimpse at how special education teachers promote reading comprehension. Learning Disability Quarterly, 33(2), 59-74.

Kolić-Vehovec, S., Rončević Zubković, B. \& Pahljina-Reinić, R. (2014). Development of metacognitive knowledge of reading strategies and attitudes toward reading in early adolescence: The effect on reading comprehension. Psihologijske teme, 23(1), 77-98.

Kuzu, T. S. (2004). Etkileşimsel modele uygun okuma öğretiminin Türkçe bilgilendirici metinleri anlama düzeyine etkisi. Ankara Üniversitesi Eğitim Bilimleri Fakültesi Dergisi, 37(1), 55-77. 
Leech, N. L. \& Onwuegbuzie, A. J. (2007). An array of qualitative data analysis tools: A call for data analysis triangulation. School psychology quarterly, 22(4), 557.

Li, W. (2013). A Study of Metacognitive Awareness of Non-English Majors in L2 Listening. Journal of Language Teaching \& Research, 4(3).

Martens, D. (2005). Research methods in education and psychology: Integrating diversity with quantitative approaches. Thousand Oaks: Sage.

Maxwell, J. A. \& Loomis, D. M. (2003). Mixed methods design: An alternative approach. Handbook of mixed methods in social and behavioral research, 1(2003), 241-272.

McInerney, D. M. (2013). Educational psychology: Constructing learning. Pearson Higher Education AU.

Mendoza-Denton, R. \& Ayduk, Ö. (2015). Coengagement, coconstruction, coevocation: Three principles to bridge relationships and social cognition.

Merriam, S. B. (2002). Introduction to qualitative research. Qualitative research in practice: Examples for discussion and analysis, 1(1), 1-17.

Merriam, S. B. (2013). Nitel araştırma: Desen ve uygulama için bir rehber (3. Baskıdan Çeviri) S. Turan (Çev. Ed.). Ankara: Nobel Yayın Dağıtım.

Miles, M. B. \& Huberman, A. M. (2015). Nitel veri analizi. Çev. Ed Sadegül Akbaba Altun ve Ali Ersoy). Ankara: Pegem Akademi.

Miller, P. (2006). What the visual word recognition skills of prelingually deafened readers tell about their reading comprehension problems. Journal of Developmental and Physical Disabilities, 18(2), 91-121.

Mokhtari, K. \& Reichard, C. A. (2002). Assessing students' metacognitive awareness of reading strategies. Journal of educational psychology, 94(2), 249.

Morse, J. M. \& Niehaus, L. (2009). Mixed methods design. Walnut Creek.

National Reading Panel. (2000). Teaching children to read: An evidence-based assessment of the scientific research literature on reading and its implications for reading instruction. Washington, DC: National Institute of Child Health and Human Development. www.nichd.nih.gov/publications/nrp/upload/smallbook_pdf.pd

Ness, R. (2006). Language Development and Learning to Read: The Scientific Study of How Language Development Affects Reading Skill. Childhood Education, 83(2), 114-115.

Noushad, P. P. (2008). Cognitions about cognitions: The theory of metacognition. ERIC Clearinghouse.

O'Reilly, T. \& McNamara, D. S. (2007). The impact of science knowledge, reading skill, and reading strategy knowledge on more traditional "high-stakes" measures of high school students' science achievement. American educational research journal, 44(1), 161-196.

Özdemir, S. (2018). Öğretmen adaylarının okuma stratejilerini kullanma düzeyleri. Bartın Üniversitesi Eğitim Fakültesi Dergisi, 7(1), 296-315.

Özen, F. ve Durkan, E. (2016). Üstbilişsel okuma stratejileri kullandırma ölçeğinin geliştirilmesi, bir geçerlilik ve güvenilirlik çalışması. Turkish Studies, International Periodical for the Languages, Literature and History of Turkish or Turkic, 11(14), 565-586.

Özsoy, G. ve Günindi, Y. (2011). Okulöncesi öğretmen adaylarının üstbilişsel farkındalık düzeyleri. Elementary Education Online, 10(2).

Papleontiou-Louca, E. (2003). The concept and instruction of metacognition. Teacher development, 7(1), 9-30.

Paris, S. G., Carpenter, R. D., Paris, A. H. \& Hamilton, E. E. (2005). Spurious and genuine correlates of children's reading comprehension. Children's reading comprehension and assessment, 131160.

Patton, M. Q. (2014). Qualitative research \& evaluation methods: Integrating theory and practice. Sage publications.

Perfetti, C. (2007). Reading ability: Lexical quality to comprehension. Scientific studies of reading, 11(4), 357-383.

Phakiti, A. (2003). A closer look at the relationship of cognitive and metacognitive strategy use to EFL reading achievement test performance. Language testing, 20(1), 26-56. 
Pressley, M. (2000). Development of grounded theories of complex cognitive processing: Exhaustive within-and between study analyses of think-aloud data. Issues in the measurement of metacognition, 262-296.

Pressley, M. (2002). Comprehension strategies instruction: A turn-of-the-century status report. Comprehension instruction: Research-based best practices, 11-27.

Pressley, M. (2002). Metacognition and self-regulated comprehension. What research has to say about reading instruction, 3, 291-309.

Pressley, M., Brown, R., El-Dinary, P. B. \& Allferbach, P. (1995). The comprehension instruction that students need: Instruction fostering constructively responsive reading. Learning Disabilities Research \& Practice.

Pressley, M. \& Afflerbach, P. (1995). Verbal protocols of reading: The nature of constructively responsive reading. Routledge.

Pressley, M. \& Harris, K. R. (2009). Cognitive strategies instruction: From basic research to classroom instruction. Journal of Education, 189(1-2), 77-94.

Pressley, M. \& McCormick, C. (1995). Cognition, teaching, and assessment. New York: HarperCollins College Publishers.

Roeschl-Heils, A., Schneider, W. \& van Kraayenoord, C. E. (2003). Reading, metacognition and motivation: A follow-up study of German students in grades 7 and 8. European journal of psychology of education, 18(1), 75-86.

Schneider, W. (2010). Metacognition and memory development in childhood and adolescence. Metacognition, strategy use, and instruction, 54-81.

Schraw, G. (2001). Promoting general metacognitive awareness. In Metacognition in learning and instruction (pp. 3-16). Springer, Dordrecht.

Sheorey, R. \& Mokhtari, K. (2001). Differences in the metacognitive awareness of reading strategies among native and non-native readers. System, 29(4), 431-449.

Silverman, D. (2013). Doing qualitative research: A practical handbook. SAGE publications limited.

Steinbach, J.C. (2010). The effect of metacognitive strategy instruction on writing. Lexington: First Edition.

Stewart, J. \& Landine, J. (1995). Study Skills from a Metacognitive Perspective. Guidance \& Counselling, 11(1), 16-20.

Sulak, S. E. ve Behriz, A. (2018). Sınıf Öğretmenlerinin Türkçe Derslerinde Öğrencilerine Üstbilişsel Okuma Stratejilerini Kullandırma Düzeylerinin Incelenmesi. Sosyal Bilimler Arastirmalari Dergisi, 8(2).

Sutiyatno, S. \& Sukarno, S. (2019). A Survey Study: The Correlation between Metacognitive Strategies and Reading Achievement. Theory and Practice in Language Studies, 9(4), 438-444.

Teddlie, C. \& Tashakkori, A. (2003). Major issues and controversies in the use of mixed methods in the social and behavioral sciences. Handbook of mixed methods in social and behavioral research, 1, 13-50.

Teddlie, C. \& Yu, F. (2007). Mixed methods sampling: A typology with examples. Journal of mixed methods research, 1(1), 77-100.

Topuzkanamış, E. ve Maltepe, S. (2010). Öğretmen adaylarının okuduğunu anlama ve okuma stratejilerini kullanma düzeyleri. Tübar-27, 655-677.

Vagle, M. D. (2009). Locating and exploring teacher perception in the reflective thinking process. Teachers and Teaching: theory and practice, 15(5), 579-599.

Van Gelderen, A., Schoonen, R., Stoel, R. D., De Glopper, K. \& Hulstijn, J. (2007). Development of adolescent reading comprehension in language 1 and language 2: A longitudinal analysis of constituent components. Journal of Educational Psychology, 99(3), 477.

Vista, A. (2013). The role of reading comprehension in maths achievement growth: Investigating the magnitude and mechanism of the mediating effect on maths achievement in Australian classrooms. International Journal of Educational Research, 62, 21-35.

Wade, S. E., Trathen, W. \& Schraw, G. (1990). An analysis of spontaneous study strategies. Reading Research Quarterly, 147-166. 
Wang, A. Y. (1993). Cultural-familial predictors of children's metacognitive and academic performance. Journal of Research in Childhood Education, 7(2), 83-90.

Williams, L. \& Hall, K. (2010). Exploring Students' Reading Attitudes. Journal of Reading Education, 35(2).

Wilson, J. (2001). Methodological Difficulties of Assessing Metacognition: A New Approach.

Yıldırım, A., ve Şimşek, H. (2013). Sosyal bilimlerde nitel araştırma yöntemleri. (9. Genişletilmiş Baskı) Ankara: Seçkin Yayınevi.

Yin, R. K. (2003). Designing case studies. Qualitative Research Methods, 359-386.

\section{Introduction}

\section{Extended Abstract}

In the field of education, teachers play an important role in terms of revealing their abilities for their students' emotions and actions, making the teaching and learning process more comfortable and successful, and directing their cognitive processes (Azevado \& ALeven, 2013; Oxford, 2013). The objective of the research is to determine the levels of primary school teacher candidates' getting the sutudents to use metacognitive reading strategies within the scope of teaching practice course.

\section{Method}

In the study, the convergent pattern was used as a mixed methods pattern in which the qualitative and quantitative findings were combined in the interpretation phase. With the convergent pattern, the quantitative and qualitative data were collected, analyzed separately, and interpreted by comparing and correlating the two data groups. The quantitative part of the study consists of 114 primary school teacher candidates in the Department of Primary School Teaching at the Faculty of Education, Çanakkale Onsekiz Mart University, Turkey during the 2019-2020 academic year. 12 primary school teacher candidates determined through the criterion sampling method constitute the qualitative study group of the research. The quantitative data of the study were obtained using the Metacognitive Reading Strategies Utility Scale developed by Özen and Durkan (2016). A semistructured observation form was created to show how and to what extent the primary school teacher candidates applied the sub-dimensions of the Metacognitive Reading Strategies Utility Scale. Behaviours in the observation form were structured using binary ratings: "Observed" and "Not Observed" (0). Observations were carried out in Turkish lessons for 4 weeks within the scope of Teaching Practice I.

In the analysis of the quantitative data, t-test and one-way analysis of variance test were used for parametric sub-dimensions, whereas Mann Whitney U Test and Kruskal Wallis H Test SPPS package program were used for non-parametric sub-dimensions. Descriptive analysis was used in the qualitative data obtained through the observation form, and the results of the analysis obtained by means of observations were presented in the tables. For validity and reliability studies for the qualitative part of the research, first of all, expert opinions about the data collection tool for the observation form were obtained and certain criteria (credibility, confirmability, reliability) were achieved. The primary school teacher candidates who participated in the study were coded as SÖA1, SÖA2, ..., SÖA12.

\section{Result and Discussion}

It was observed that there was no significant difference between the primary school teacher candidates' levels of before reading, during reading, after reading and reading evaluation subdimensions in the Metacognitive Reading Strategies Utility Scale and practicing Turkish lessons within the context of teaching practice course. It was found that there was a significant difference between the teacher candidates' levels of utilizing the during reading sub-dimension in the Metacognitive Reading Strategies Utility Scale and their observations in Turkish lessons within the context of school experience in favour of not making observations. It was found that there was a significant difference between the reading preparation, during reading, after reading and reading evaluation sub-dimensions in the Metacognitive Reading Strategies Utility Scale and gender in favour of women. It was also 
determined that there was no significant difference between the during reading sub-dimension in the Metacognitive Reading Strategies Utility Scale and grade point average.

In the reading preparation and reading evaluation sub-dimensions, between the total score of the Metacognitive Reading Strategies Utility Scale and grade point average, it was determined that there was a significant difference between 2,00-2,49 Grade point average (GPA) and 2,59-2,99 GPA in favour of 2,50-2,99 GPA and that there was a significant difference between 2.00-2.49 GPA and 3.003.49 GPA in favour of 3.00-3.49 GPA.

It was observed that not all of the primary school teachercandidates asked their students to question the reading text in Turkish lessons in the reading preparation sub-dimension. It was determined that the teacher candidates asked their students to answer the questions related to the text in the after reading sub-dimension and that they did not, however, ask their students to find the supporting ideas in the text.

When the results of the study are considered, it was found out that the individual characteristics of the primary school teacher candidates, such as grade point average and gender, made a difference on the Metacognitive Reading Strategies Utility Scale and that the primary school teacher candidates' observations in Turkish lessons were effective in utilizing these strategies although practicing in Turkish lessons did not make a difference in terms of making these strategies effective. It was observed that the primary school teacher candidates were generally not able to display adequate behaviour towards utilizing these strategies and that they, however, utilized the during reading and reading evaluation sub-dimensions in the Metacognitive Reading Strategies Utility Scale in the classroom.

In the study, it was found that the primary school teacher candidates could not utilize these strategies in terms of the reading preparation, during reading, after reading and reading evaluation sub-dimensions because of low number of class hours, crowded classes, lack of effective time management in the classroom, and some reasons arising from classroom management. It was also found that they did not use what they learned in their undergraduate programs both in vocational knowledge courses and elective courses pool and that they did not ask their students to animate and dramatize the characters and events in the reading texts. At this point, this situation is thought to be due to the fact that the teacher candidates were not fully competent in how to use these strategies and that they did not have the necessary skills in terms of time management. In the light of the results of the research, it is recommended to provide trainings with applications within the scope of vocational knowledge courses in teacher education programs for these strategies, and to develop instructional designs by developing various techniques. 